
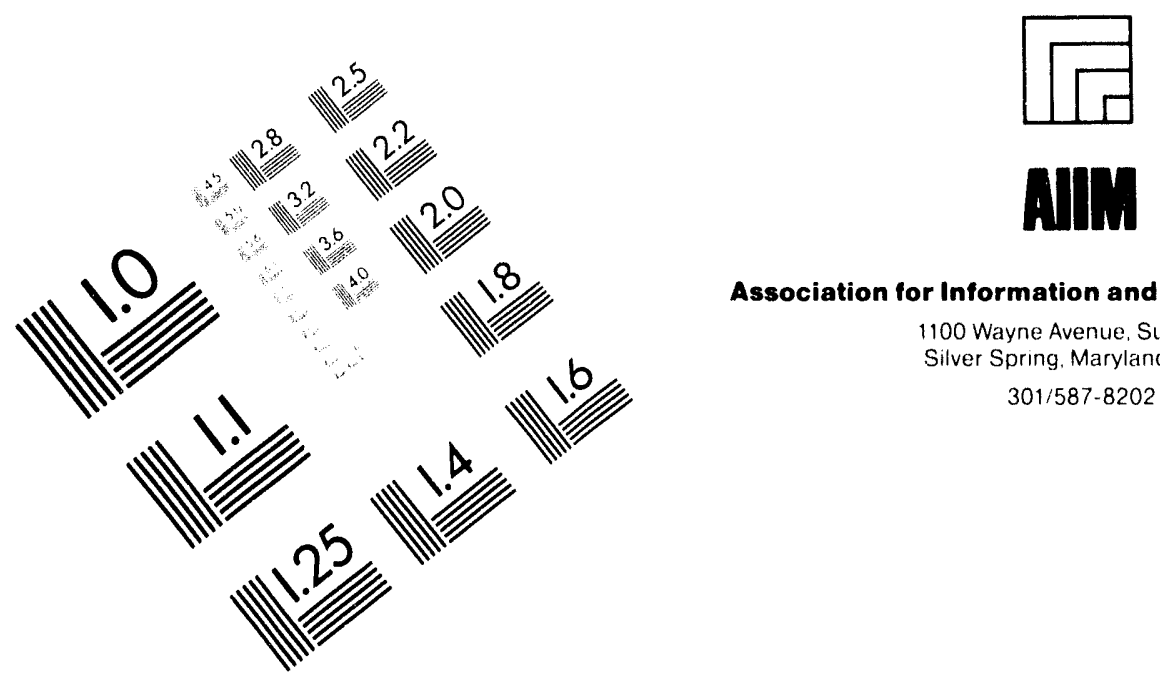

Association for Information and Image Management

1100 Wayne Avenue. Suite 1100

Silver Spring. Maryland 20910

301/587-8202

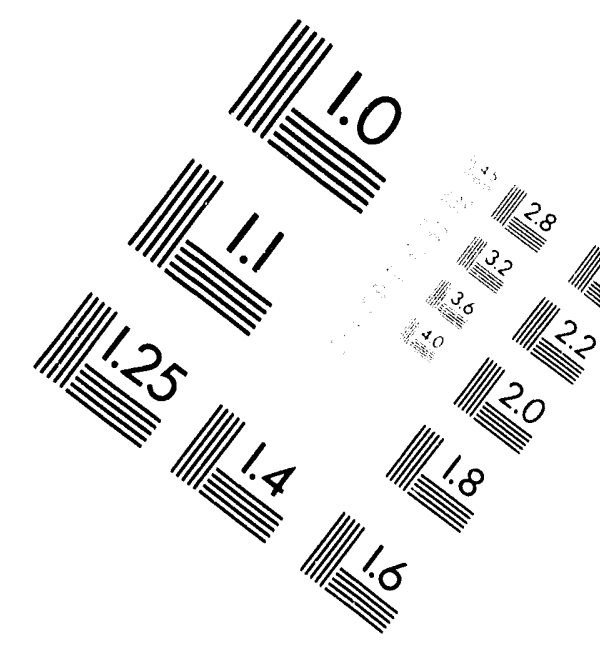

Centimeter

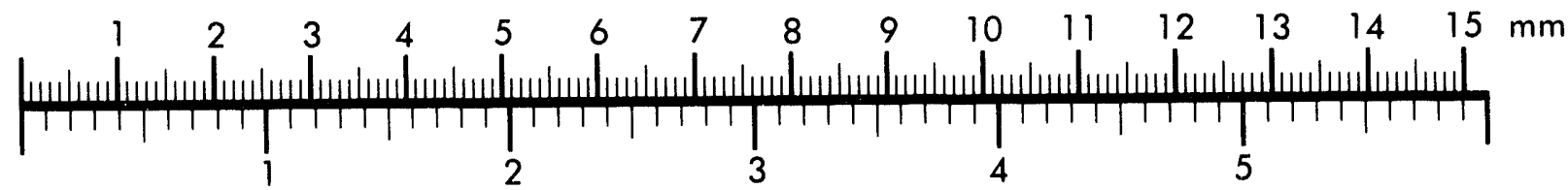

Inches
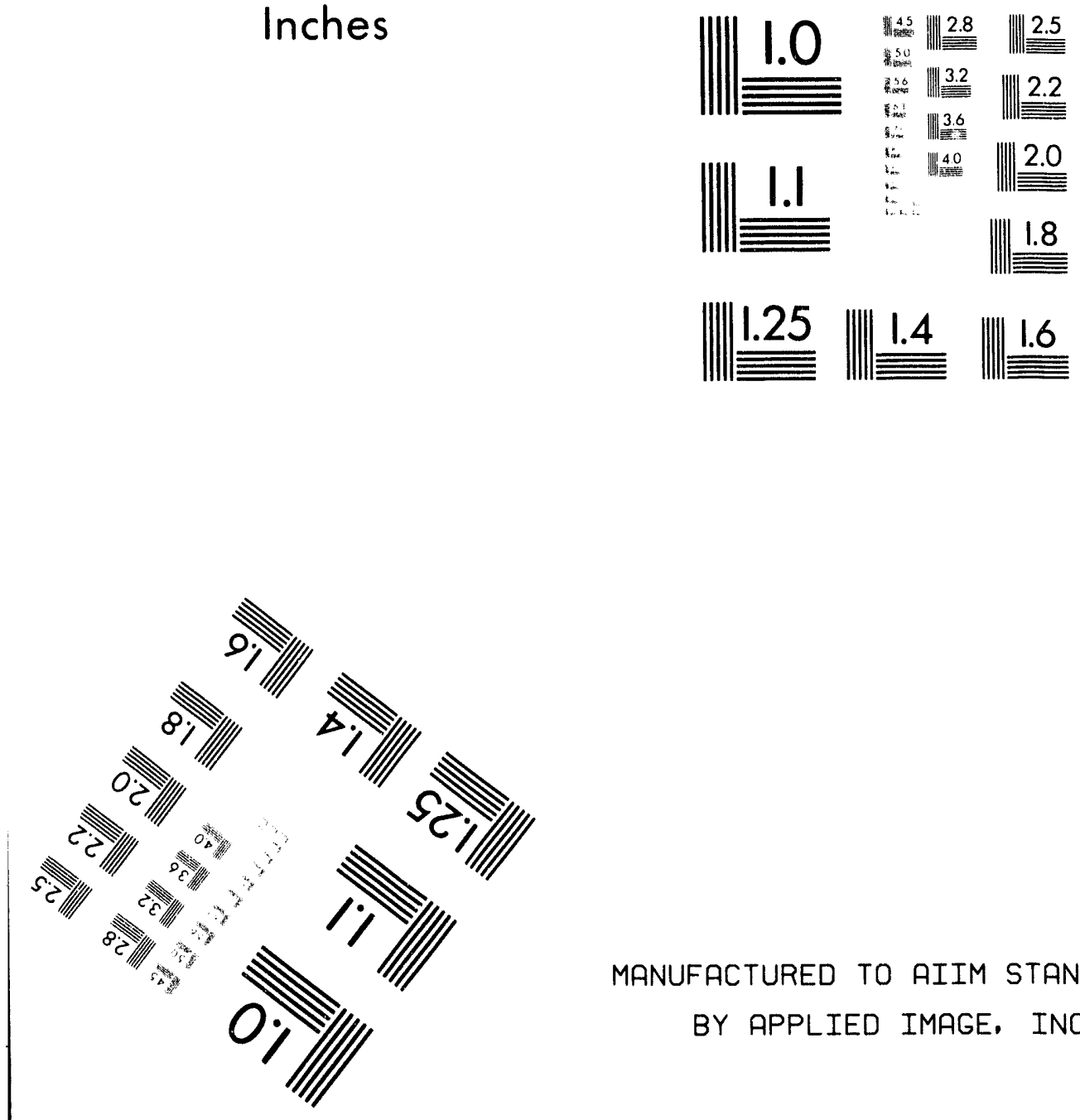

MANUFACTURED TO AIIM STANDARDS

BY APPLIED IMAGE. INC.

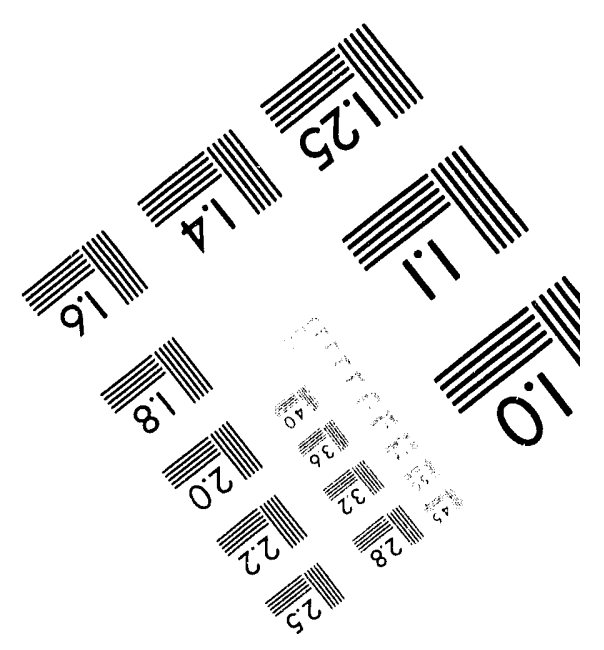



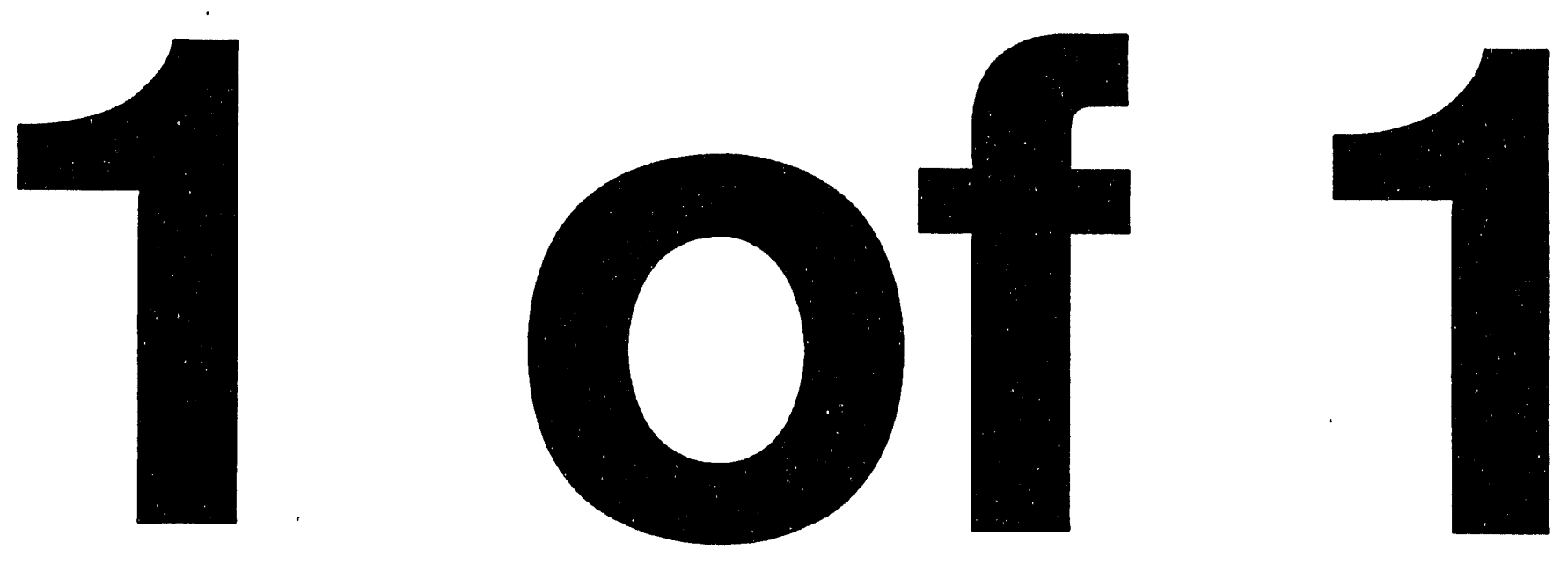
Available from

Superintentendent of Documents

U.S. Government Printing Office

Mail Stop SSOP

Washington, D.C. 20402-9328

A year's subscription consists of 12 softbound issues, 4 indexes, and 2-4 hardbound editions for this publication.

\author{
Single copies of this publication \\ are available from \\ National Technical Information Service \\ Springfield, VA 22161
}

Errors in this publication may be reported to the Division of Freedom of Information and Publications Services

Office of Administration

U.S. Nuclear Regulatory Commission

Washington, DC 20555-0001

(301/492-8925) 
NUREG-0750

Vol. 39, No. 2

Pages 47-90

\section{NUCLEAR REGULATORY COMMISSION ISSUANCES}

February 1994

This report includes the issuances received during the specified period from the Commission (CLI), the Atomic Safety and Licensing Boards (LBP), the Administrative Law Judges (ALJ), the Directors' Decisions (DD), and the Denials of Petitions for Rulemaking (DPRM).

The summaries and headnotes preceding the opinions reported herein are not to be deemed a part of those opinions or have any independent legal significance.

Prepared by the

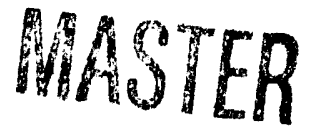

Division of Freedom of Information and Publications Services

Office of Administration

U.S. Nuclear Regulatory Commission

Washington, DC 20555-0001

(301/492-8925)

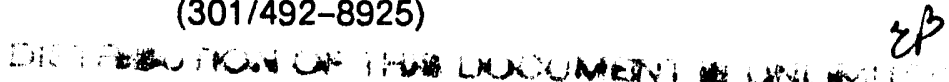




\section{COMMISSIONERS}

Ivan Selin, Chairman

Kenneth C. Rogers

Forrest J. Remick

E. Gail de Planque

B. Paul Cotter, Jr., Chief Administrative Judge, Atomic Safety and Licensing Board Panel 


\section{CONTENTS}

Issuances of the Atomic Safety and Licensing Boards

\section{BABCOCK AND WILCOX COMPANY}

(Pennsylvania Nuclear Services Operations, Parks Township, Pennsylvania)

Docket 70-364-ML-Ren (ASLBP No. 94-687-01-ML-Ren)

(Materials License No. SNM-414)

MEMORANDUM AND ORDER, LBP-94-4, February 2, $1994 \ldots \ldots .47$

SEQUOYAH FUELS CORPORATION and GENERAL ATOMICS

(Gore, Oklahoma Site Decontamination and Decommissioning Funding)

Docket 40-8027-EA (ASLBP No. 94-684-01-EA)

(Source Material License No. SUB-1010)

MEMORANDUM AND ORDER, LBP-94-5, February 24, $1994 \ldots \ldots .54$

Issuances of Directors' Decisions

NORTHEAST NUCLEAR ENERGY COMPANY

Docket 50-423

DIRECTOR'S DECISION UNDER 10 C.F.R. $\S 2.206$,

DD-94-1, February 9, 1994

U.S. DEPARTMENT OF ENERGY

(Hanford Site)

DIRECTOR'S DECISION UNDER 10 C.F.R. $\$ 2.206$,

DD-94-2, February 22, $1994 \ldots \ldots \ldots \ldots \ldots \ldots \ldots \ldots \ldots . \ldots 6$ 


\section{Atomic Safety and Licensing Boards Issuances}

ATOMIC SAFETY AND LICENSING BOARD PANEL

B. Paul Cotter, Jr., * Chief Administrative Judge

Robert M. Lazo, * Deputy Chief Administrative Judge (Executive)

Frederick J. Shon, * Deputy Chief Administrative Judge (Technical)

\section{Members}

Dr. George C. Anderson Charles Bechhoefer Poter B. Bloch*

G. Paul Bollwerk III* Glenn O. Bright Dr. A. Dixon Callihan Dr. James H. Carpenter

Dr. Richard F. Cole*

Dr. Thomas E. Elleman

Dr. George A. Ferguson

Dr. Harry Foreman

Dr. Richard F. Foster
James P. Gleason* Dr. David L. Hetrick Emest E. Hill Dr. Frank F. Hooper Elizabeth B. Johnson Dr. Walter H. Jordan Dr. Charles N. Kelber* Dr. Jerry R. Kline* Dr. Poter S. Lam* Dr. James C. Lamb III Dr. Emmeth A. Luebke Morton B. Margulies*
Dr. Kenneth A. McCollom Marshall E. Miller Thomas S. Moore* Dr. Peter A. Morris Thomas D. Murphy* Dr. Richard R. Parizek Dr. Harry Rein Lester S. Rubenstein Dr. David R. Schink Ivan W. Smith* Dr. George F. Tidey Sheldon J. Wolfe 
UNITED STATES OF AMERICA

NUCLEAR REGULATORY COMMISSION

\title{
ATOMIC SAFETY AND LICENSING BOARD PANEL
}

\author{
Before Administrative Judges: \\ Ivan W. Smith, Presiding Officer \\ Dr. Peter S. Lam, Special Assistant
}

In the Matter of

Docket No. 70-364-ML-Ren

(ASLBP No. 94-687-01-ML-Ren)

(Materials License No. SNM-414)

\section{BABCOCK AND WILCOX COMPANY \\ (Pennsylvania Nuclear Services Operations, \\ Parks Township, Pennsylvania)}

February 2, 1994

\section{MEMORANDUM AND ORDER \\ (Authorizing Amendment to Hearing Request)}

\section{BACKGROUND}

The NRC is considering the application for the renewal of the special nuclear materials license issued to the Babcock and Wilcox Company Pennsylvania Nuclear Service Operation (B\&W or Applicant) for its facility located in Parks Township, Armstrong County, Pennsylvania (Parks Township facility). In a Federal Register notice of November 3, 1993 (58 Fed. Reg. 58,711), the Commission published the required notice of the license renewal consideration. The notice generally described the operations at the Parks Township facility and provided an opportunity for any person whose interest may be affected to file a request for hearing on B\&W's application. The notice also stated that any request for hearing must comply with 10 C.F.R. Part 2, Subpart L, which specifies the informal hearing procedures for adjudications in materials licensing proceedings. 
On January 5, 1994, Citizens Action for a Safe Environment (CASE), by Patricia J. Ameno, and Kiski Valley Coalition to Save Our Children (the Coalition), by John Bologna, filed a timely joint request for a hearing.'

A B\&W official opposes the request for hearing, stating only that the requestors' "letter does not satisfy any of the requirements for requesting a hearing identified in 10 CFR Part 2, Subpart L."2

On January 24, 1994, the NRC Staff filed its notice that it desires to participate as a party to the adjudication and answered the joint request. The Staff opposes any hearing on the grounds that the Petitioners have not satisfied NRC requirements regarding standing to intervene and have not demonstrated how the areas of their concerns are germane to the subject matter of the proceeding.

\section{DISCUSSION}

\section{A. Novel Situation - Insufficient Information}

This proceeding, in that it involves a general license renewal of the particular activities under the Parks Township facility license, is novel as it pertains to the issue of standing to intervene.

At the outset, the requestors, Staff, and the Applicant should be aware that, except for the description of the Parks Township facility contained in the Federal Register notice and allusions to it in the hearing request, Judge Lam and I know virtually nothing about the facility. The requestors apparently assume, incorrectly, that their request for a hearing will be assessed by us in the context of the NRC's broad, institutional information about the facility. The Staff's response and $\mathrm{B} \& \mathrm{~W}$ 's terse letter opposing the hearing request provide no factual background against which we may evaluate the request. ${ }^{3}$

The requestors have the burden of demonstrating that their request should he granted. They have not shown in necessary detail that they have standing to intervene in this proceeding. See, generally, Staff Response at 3-9. On the other hand, one can fairly surmise from the request and Federal Register notice that the requestors may actually have standing, but are unversed in NRC standing rules.

Were this a formal proceeding under Subpart G of Part 2, persons seeking to intervene would be permitted to amend their intervention petitions without

\footnotetext{
'Pursuant to the Petitioners' request, on December 17, 1993, the Secretary of the Commission extended the time to request a hearing until January $6,1994$.

${ }^{2}$ Letter dated January 13, 1994, from B.L. Haertjens, B\&W Nuclear Environmental Services to ASLBP Chief Judge B. Paul Cotter.

${ }^{3}$ Although their answering pleadings could have been more helpful, neither the Staff nor B\&W is required now to provide a factual background in opposing the request. The Staff will not be required to provide a hearing file until and unless a hearing is ordered.
} 
leave of the presiding officer before a final ruling on their standing. 10 C.F.R. $\$ 2.714(\mathrm{a})(3)$. Thus, under Subpart G, Petitioners have a valuable opportunity to cure defects in their initial petitions after the defects have been disclosed in preliminary pleadings and rulings. There is no parallel opportunity under the informal rules of Subpart $L$.

Subpart L rules, by their very definition, are intended to be informal. My primary duty at this stage of the proceeding is to treat the hearing request fairly. If the hearing request is otherwise meritorious - and it appears here that the requestors have a good chance of establishing their standing - I may excuse unskilled pleading and inexperience and provide another opportunity to have their worries and concerns heard.

Therefore, as a matter of discretion, I am exercising the general powers of a presiding officer in Subpart L proceedings (10 C.F.R. \$ 2.1209) to provide the requestors the opportunity to amend their request in accordance with the terms of the following order and discussion. ${ }^{4}$

\section{B. Standing to Intervene}

Subpart $L$ requires that the person requesting a hearing meet judicial standards for standing. 10 C.F.R. $\$ 2.1205(\mathrm{~g})$. This rule is simply a restatement of longstanding Commission requirements that a prospective intervenor, who believes that his or her interests may be affected by a proceeding, must, as if in a court of law, show "a concrete and particularized injury that is fairly traceable to the challenged action." Transnuclear Inc. (Export of 93.15\% Enriched Uranium), CLI-94-1, 39 NRC 1, 5 (1994), citing Cleveland Electric Illuminating Co. (Perry Nuclear Power Plant, Unit 1), CLI-93-21, 38 NRC 87, 92 (1993). This injury, known as "injury-in-fact" in legal discussions, must be actual but can include threatened injury, and must be arguably within the "zone of interest" of the statutes governing this proceeding: the Atomic Energy Act and the National Environmental Policy Act (as administered by the NRC). Sacramento Municipal Utility District (Rancho Seco Nuclear Generating Station), CLI-92-2, 35 NRC 47, 56 (1992); Metropolitan Edison Co. (Three Mile Island Nuclear Station, Unit 1), CLI-83-25, 18 NRC 327, 332 (1983). For example, petitioners in NRC proceedings may not intervene on the grounds that the challenged action would injure their interests as local taxpayers.

\footnotetext{
${ }^{4}$ In exercising this discretion, I am following the precedents set in at least two earlier Subpart $L$ proceedings. In Babcock and Wilcox (Apollo, Pennsylvania Fuel Fabrication Facility), LBP-92-24, 36 NRC 149 (1992), Judge Bollwerk granted the petitioners leave to supplement their petitions on issues of standing and areas of concerns "germane" to the proceeding. In the Apollo proceeding, B\&W acknowledged that the presiding officer has such discretion. Id. at 151-52. See also Northem States Power Co. (Pathfinder Atomic Plant), LBP-89-30, 30 NRC $311,312.17$ (1989).
} 
CASE and the Coalition state that they request a hearing on behalf of the citizens of the Kiski Valley, especially the elderly and invalids, and they seek to protect "property values and the health and safety of the remaining general population." As laudable as such concern might be, the requestors may not undertake to represent the general public as if they were private attorneys general. They must establish "injury-in-fact" and standing, either as an organization whose organizational interests may be affected and injured by the proposed license renewal, or demonstrate that one or more of their members are affected and injured by the proposed license renewal. Houston Lighting and Power Co. (South Texas Project, Units 1 and 2), ALAB-549, 9 NRC 644, 646 (1979).

Almost always in NRC proceedings, intervening organizations derive standing to intervene from the standing of their members. To establish standing from the standing of its members, an organization must show that one or more of its members "are suffering immediate or litreatened injury as a result of the challenged action of the sort that would make out a justifiable case had the members themselves brought suit . . . ." Id. at 647, citing Warth $v$. Seldin, 422 U.S. 490, 511 (1975).

Normally an organization who wishes to represent its members in an NRC proceeding must identify one or more members by name and address and demonstrate that the named members have authorized the petitioning organization to represent their interests in the proceeding. ${ }^{5}$ The organization must specify how the proposed action (in this case the facility license renewal) would cause or threaten "injury-in-fact" to the members who have authorized the intervention on their behalf.

In most cases in NRC practice, whether a petitioner (or petitioner's member) would sustain an "injury-in-fact" as a result of a proposed licensing action has been determined by whether the individual lives or engages in activities near the nuclear facility in question. Thus, a petitioner may demonstrate the potential for injury if the petitioner, or its members, live, work, or play, for example, in an area that might be affected by the release of nuclear radiation from a large commercial nuclear power plant. In Virginia Electric and Power Co. (North Anna Power Station, Units 1 and 2), ALAB-522, 9 NRC 54, 56-57 (1979), the Appeal Board would not rule out, as a matter of law, derivative standing where a member of the petitioning organization lived about 35 miles from the facility,

\footnotetext{
${ }^{5}$ In a very limited number of situations, the authorization by the members to be represented in a specific proceeding may be presumed if the organization is specifically empowered by its members to represent their interests in all matters similar to the proceeding at bar. E.g., Georgia Power Co. (Vogtle Electric Generating Plant, Units 1 and 2), LBP-91-33, 34 NRC 138, 140-41 (1991). The prudent approach, however, would be to demonstrate that the member or members whose interests are to be represented by the petitioning organization have specifically authorized the organization to represent them in the very proceeding at bar.
} 
and where another member lived 45 miles away but engaged in canoeing in close proximity to the plant. Id. at 57 .

Also, in North Anna, the Appeal Board noted that it had never required a petitioner in close proximity to a facility in question to specify the:

causal relationship between injury to an interest of a petitioner and the possible results of the proceeding. Rather, close proximity has always been deemed to be enough, standing alone, to establish the requisite interest.

Id. at 56 (footnote omitted), citing, e.g., Gulf States Utilities Co. (River Bend Station, Units 1 and 2), ALAB-183, 7 AEC 222, 223-24 (1974), and cases there cited. See also Armed Forces Radiology Research Institute (Cobalt-60 Storage Facility), ALAB-682, 16 NRC 150, 154 (1982).

More recently, however, NRC proceedings have involved rather narrow factual situations as contrasted with the general operation of a nuclear power facility. In Florida Power and Light Co. (St. Lucie Nuclear Power Plant, Units 1 and 2), CLI-89-21, 30 NRC 325, 329-30 (1989), the Commission explained:

\begin{abstract}
It is true that in the past, we have held that living within a specific distance from the plant is enough to confer standing on an individual or group in proceedings for construction permits, operating licenses, or significant amendments thereto such as the expansion of the capacity of a spent fuel pool. See, e.g., Virginia Electric and Power $C_{0}$. (North Anna Power Station, Units 1 and 2), ALAB-522, 9 NRC 54 (1979). However, those cases involved the construction or operation of the reactor itself, with clear implications for the offsite environment, or major alterations to the facility with a clear potential for offsite consequences. See, e.g., Gulf States Utilities $C_{0}$. (River Bend Station, Units 1 and 2), ALAB-183, 8 AEC 222, 226 (1974). Absent situations involving such obvious potential for offsite consequences, a petitioner must allege some specific "injury in fact" that will result from the action taken. . . .
\end{abstract}

We learn from the foregoing decisions that, in some cases, standing and injury-in-fact can be inferred from proximity to the facility in question. In other cases, those without obvious offsite implications, the petitioner must, as the St. Lucie decision held, allege the specific injury complained of.

In the case of the Park Township facility, the Applicant seeks a renewal of the license for full operation, as contrasted to a narrow amendment to the license. On the other hand the facility, I assume, does not present the same potential for offsite releases as would a commercial nuclear power reactor.

Requestors allege the threat of offsite releases of radioactivity - in fact, they allege that such releases have already occurred. The Federal Register notice also notes that very small releases of radioactivity are expected from the operations through air, water, and food pathways. 58 Fed. Reg. at 58,712.

If CASE and the Coalition choose to supplement their requests to address the issue of their standing to intervene, they should: (1) explain in detail whether 
the threatened injury to their named members should be inferred from their proximity to the facility itself; or (2) allege in detail a specific injury or threat of injury to the health, safety, or property of their named members from the continued operation of the facility; or (3) both.

The Staff and B\&W may of course respond to the requestors' amended request. Since the potential for offsite releases from the Parks Township facility is not generally known, the allegations and answers pertaining to standing must be supported by statements of fact. For the purpose of standing only, factual statements may, if necessary, be supported by documentation provided to us and to the parties. ${ }^{6}$ Maps of the area showing the relative distances of physical aspects of the amended request would be helpful.

\section{Requestors' Areas of Concerns}

Requests for a hearing must describe in detail the requestor's areas of concern about the licensing activity subject to the hearing. 10 C.F.R. $\$ 2.1205$ (c)(3). However, requestors need not set forth all of their concerns until they have been given access to the hearing file. They need only identify the areas of concerns germane to the proceeding they wish to raise. This statement of concerns need not be extensive but miust fall generally within the scope of the hearing.?

The Staff argues that in every case the requestors have failed to adequately specify their areas of concern. Although I will defer final ruling on the "areasof-concern" aspects until the requestors have filed their amended request, I wish to note that, as a general matter, I believe that the Staff's arguments are overly technical. These arguments are better suited to a criticism of specific concerns that need not be specified until later in the proceeding. As noted, requestors now need to establish only that their areas of concern are germane or relevant to the licensing action. Some of the requestors' statements clearly express an area of concern. For example, paragraphs on the second page unmistakably express worries about the threat of offsite radiological contamination from the Parks Township facility. On the other hand, I remind the requestors that Judge Lam and I know only what is stated in the Federal Register notice and the hearing request letter. For example, requestors' reference to the "Shot Blasting Process" is not clear to us.

I will permit CASE and the Coalition to amend their request to better explain the "areas of concern." However the requestors are not, by this order, authorized

\footnotetext{
${ }^{6}$ Standing to intervene, unlike the merits of contentions, may be the subject of a limited evidentiary inquiry before intervention is granted. Consumers Power Co. (Midland Plant, Units 1 and 2), LBP-78-27, 8 NRC 275, 277 n.1 (1978), citing Florida Power and Light Co. (St. Lucie Nuclear Power Plant, Unit 2), CLI-78-12, 7 NRC 939, 948-49 (1978).

${ }^{7}$ See Statement of Considerations, Informal Hearing Procedures for Materials Licensing Adjudication, 54 Fed. Reg. 8269, 2-SC-22, 25 (Feb. 28, 1989).
} 
to add new areas of concern; they are limited to explaining those areas already specified. $^{8}$

\section{Additional Guidance}

In the foregoing sections, I have discussed in separate categories the legal concepts of standing to intervene (including "injury-in-fact") and "areas of concern germane to the proceeding." NRC practice can be daunting even for experienced lawyers. Recognizing that the requestors are inexperienced and are not represented by legal counsel, it might be helpful for them to understand that "injury-in-fact" and "areas of concern germane to the proceeding" are not necessarily different factual concepts. Logically, the two legal concepts are often factually one and the same. For example, if the requestors assert as "injury-infact" the threat of offsite radiological contamination from the facility and their "areas of concern" is the same threat, they may simply explain that situation.

Further, I urge the requestors to study very carefully the foregoing discussion of standing to intervene. If the amended request depends upon standing derived from its members, it must expressly address every element of derivative standing: (1) Who are the members? (2) Where do they live, work, play, go to school, etc.? (3) How far from the facility do these activities take place? (4) Have they authorized CASE and the Coalition to represent them? If so, prove it. (5) Exactly how are the members or their property injured or threatened with injury from radiation releases from the facility?

\section{ORDER}

In accordance with the foregoing discussion:

1. Requestors CASE and the Coalition may amend their request for hearing within 20 days following the service of this order.

2. The Applicant may answer any amended request within ten days following service thereof.

3. The NRC Staff may answer within 15 days following service of any amended requests.

Ivan W. Smith, Presiding Officer ADMINISTRATIVE JUDGE

Bethesda, Maryland

February 2, 1994

\footnotetext{
${ }^{8}$ An amended petition containing new areas of concern would have to satisfy the provisions of 10 C.F.R. $\$ 2.1205(\mathrm{k})(1)$ and (2) pertaining to untimely requests for a hearing.
} 
UNITED STATES OF AMERICA

\section{NUCLEAR REGULATORY COMMISSION}

\section{ATOMIC SAFETY AND LICENSING BOARD}

\section{Before Administrative Judges:}

James P. Gleason, Chairman

Dr. Jerry R. Kine

G. Paul Bollwerk, III

Thomas D. Murphy, Alternate Board Member

In the Matter of

Docket No. 40-8027-EA

(ASLBP No. 94-684-01-EA)

(Source Material License

No. SUB-1010)

\section{SEQUOYAH FUELS CORPORATION and GENERAL ATOMICS \\ (Gore, Oklahoma Site Decontamination and Decommissioning Funding)}

February 24, 1994

In this proceeding concerning a Staff enforcement order issued in accordance with 10 C.F.R. $\$ 2.202$, the Licensing Board grants a petition for leave to intervene, concluding that (1) intervention in support of a Staff enforcement order is permitted; (2) the Petitioner established its standing to intervene in this particular proceeding; and (3) the intervention motion was timely filed. Additionally, the Licensing Board refers its ruling on the first matter to the Commission for its review. 


\section{ENFORCEMENT ACTIONS: INTERVENTION SUPPORTING ENFORCEMENT ORDER}

\section{RULES OF PRACTICE: STANDING TO INTERVENE (ENFORCEMENT ACTIONS)}

Once a party to whom a Staff enforcement order is directed requests a hearing, a person favoring the order is presented with the likelihood that an adjudicatory proceeding would be conducted that could have two possible outcomes: the presiding officer would fully sustain the order or it would not, either because the presiding officer would reject the order in whole or in part or because the order would be modified or withdrawn by some unilateral Staff action or by a settlement between the Staff and the parties contesting the order. Given these two possible outcomes, only if the person supporting the enforcement order is permitted to participate in the proceeding can it protect its interest in seeing that the order and the requirements the order imposes are sustained. Therefore, if the person supporting the order also can establish a particularized injury that it or its members will suffer in the event the order is not sustained, it is entitled to intervene as of right as a "person whose interest may be affected by the proceeding" under section 189a(1) of the Atomic Energy Act of 1954, 42 U.S.C. $\S 2239(\mathrm{a})(1)$, and/or 10 C.F.R. $\$ 2.714(\mathrm{a})(1)$.

\section{LICENSING BOARDS: JURISDICTION (STAFF ORDERS) RULES OF PRACTICE: REVIEW OF NRC STAFF'S ACTIONS;
SETTLEMENT OF CONTESTED PROCEEDINGS}

A Staff action to relax or rescind the conditions in an enforcement order that is the subject of an ongoing adjudication would be subject to review by the presiding officer with input from all parties to the proceeding. See Oncology Services Corp., LBP-94-2, 39 NRC 11, 26 n.12 (1994).

\section{RULES OF PRACTICE: SETTLEMENT OF CONTESTED PROCEEDINGS}

Pursuant to 10 C.F.R. $\$ 2.203$, any settlement between the Staff and any of the parties subject to an enforcement order must be reviewed and approved by the presiding officer. In such a circumstance, a participant intervening in support of the order would have an opportunity to vindicate its interest in having the order sustained fully by demonstrating why the settlement proposal would not be in the public interest. 


\section{RULES OF PRACTICE: STANDING TO INTERVENE (INJURY IN FACT; ZONE OF INTERESTS)}

In assessing whether an intervenor has made the necessary showing of particularized injury to establish its right to intervene in a proceeding, the presiding officer is constrained to apply contemporaneous judicial concepts of standing. See Cleveland Electric Illuminating Co. (Perry Nuclear Power Plant, Unit 1), CLI-93-21, 38 NRC 87, 92 (1993). This requires that the presiding officer assess whether the intervenor will suffer any "injury in fact" relative to its interests in the proceeding and whether those alleged interests are within the "zone of interests" protected by the pertinent statutes and regulations under which the petitioner seeks to participate in the proceeding. See id.

\section{RULES OF PRACTICE: STANDING TO INTERVENE (INJURY IN FACT)}

To establish the requisite injury in fact, a petitioner must allege a concrete and particularized injury that is fairly traceable to the action at issue and is likely to be redressed by a favorable decision in the proceeding. See Perry, CLI-93-21, 38 NRC at 92.

\section{RULES OF PRACTICE: STANDING TO INTERVENE (INJURY IN FACT)}

In reviewing affidavits on the issue of whether a petitioner has established its injury in fact so as to have standing to intervene, the presiding officer must bear in mind the often-repeated admonition to avoid "the familiar trap of confusing the standing determination with the assessment of petitioner's case on the merits." City of Los Angeles v. National Highway Traffic Safety Administration, 912 F.2d 478, 495 (D.C. Cir. 1990) (citations omitted).

\section{RULES OF PRACTICE: STANDING TO INTERVENE (INJURY IN FACT)}

If, on the basis of the presentations by the participants, the presiding officer is unable to conclude relative to an intervenor's property that there is "no potential for offsite consequences" from contamination from a licensee's site, see Perry, CLI-93-21, $38 \mathrm{NRC}$ at 95, then there has been a sufficient demonstration of injury in fact to provide standing to intervene as of right in a proceeding. 


\section{RULES OF PRACTICE: UNTIMELY INTERVENTION PETITIONS}

Although 10 C.F.R. $\$ 2.714$ (a)(1) has been interpreted to require that the latefiled factors be addressed in the initial late intervention petition, it is within a presiding officer's discretion to permit an intervenor to make a belated lateness showing. See Boston Edison Co. (Pilgrim Nuclear Power Station), ALAB-816, 22 NRC 461, 466-68 (1985).

\section{REGULATIONS: INTERPRETATION AND APPLICATION STATUTORY CONSTRUCTION OR INTERPRETATION: GENERAL RULES}

In interpreting a statute or regulation, the usual inference is that different language is intended to mean different things. See United States v. Stauffer Chemical Co., 684 F.2d 1174, 1186 (6th Cir. 1982), aff'd, 464 U.S. 165 (1984).

\section{REGULATIONS: INTERPRETATION AND APPLICATION}

\section{STATUTORY CONSTRUCTION OR INTERPRETATION: GENERAL RULES}

The inference regarding differing meanings for differing language might be negated by a showing that the purpose or history behind the language demonstrates that no difference was intended. See Stauffer Chemical Co., 684 F.2d at 1186.

\section{REGULATIONS: INTERPRETATION (10 C.F.R. §2.202(a)(3); 10 C.F.R. $\$ 2.714(\mathbf{a})(\mathbf{1}))$ \\ RULES OF PRACTICE: INTERVENTION PETITIONS (FILING DEADLINE IN PROCEEDING ON ENFORCEMENT ORDER)}

For an intervenor who wishes to become a party to a hearing to protect its interest in seeing that the Staff enforcement order challenged in a proceeding is sustained, the matter adversely affecting the petitioner's interest is not the "order," with which it agrees, but the agency's "proceeding" relative to that order, which carries the potential for overturning or modifying the order in derogation of the petitioner's interests. Therefore, the language of 10 C.F.R. \$2.202(a)(3) establishing a 20-day deadline for hearing requests by any person "adversely affected by the order" is not applicable to such a petitioner. Instead, the petitioner's intervention is governed by the terms of 10 C.F.R. $\$ 2.714(a)(1)$, which is applicable to "[a]ny person whose interest may be affected by a 
proceeding," and is subject to any time limits that are established in accordance with that section.

\section{RULES OF PRACTICE: INTERVENTION PETITIONS (FILING DEADLINE IN PROCEEDING ON ENFORCEMENT ORDER)}

If the only agency issuance providing constructive notice of a filing deadline for hearing requests is a Staff enforcement order issued in accordance with 10 C.F.R. \$2.202(a)(3) that, by its terms, is not applicable to persons who wish to intervene in support of the order, then an intervention petition filed by such a person cannot be deemed untimely for failing to meet an appropriately noticed filing deadline.

\section{INTERVENTION: ACTUAL NOTICE (ENFORCEMENT PROCEEDING)}

Even in the absence of any constructive notice of when an intervention petition must be filed, the possibility remains that an intervenor had actual notice of the pendency of an enforcement proceeding and failed to make a timely intervention request following that notice. See 54 Fed. Reg. 8269, 8272 (1989).

\section{INTERVENTION: ACTUAL NOTICE (ENFORCEMENT PROCEEDING)}

Because it is their interest in the "proceeding" rather than the "order" that is relevant for a person wishing to intervene in support of a Staff enforcement order, the pertinent actual notice was that affording the intervenor knowledge that an adjudicatory proceeding would be commenced. Receipt of the hearing request of a person adversely affected by the order constitutes such notice. By filing an intervention motion within 10 days after receipt of such a hearing request, an intervenor acts seasonably relative to that actual notice. Compare 10 C.F.R. $\$ 2.1205(c)(2)(i)$ (hearing request must be filed within 30 days of actual notice).

\section{RULES OF PRACTICE: APPELLATE REVIEW (INTERVENTION RULINGS); INTERLOCUTORY APPEALS (INTERVENTION ORDERS)}

Until a determination is made that an intervenor has proffered a litigable contention, a presiding officer's ruling that the petitioner has established its standing is not final so as to be appealable pursuant to 10 C.F.R. § 2.714a. See 
Cincinnati Gas and Electric Co. (William H. Zimmer Nuclear Power Station), ALAB-595, 11 NRC 860, 864-65 (1980).

\section{RULES OF PRACTICE: INTERLOCUTORY APPEALS (REFERRAL OF RULINGS); REFERRAL OF RULING TO COMMISSION}

Because the question of whether intervention as of right exists for a petitioner that wants to enter a 10 C.F.R. $\$ 2.202$ enforcement order proceeding to support the Staff's order is of some moment for the structure of this proceeding, as well as the Commission's adjudicatory process generally, and in order to alleviate any delay in Commission consideration of this matter pending the Licensing Board's determination regarding the admissibility of the intervenor's contentions, in accordance with 10 C.F.R. $\$ 2.730$ (f) it is appropriate for the Board to refer its ruling on the petitioner's right to intervene to the Commission for its immediate review. Cf. Statement of Policy on Conduct of Licensing Proceedings, CLI-818, 13 NRC 452, 456-57 (1981) (in licensing hearings, licensing boards should seek Commission guidance on significant legal or policy questions and should do so in a manner that will avoid delay in the proceeding).

\section{MEMORANDUM AND ORDER (Granting Intervention Motion; Referring Ruling to the Commission)}

This proceeding is before us to consider the challenge of Sequoyah Fuels Corporation (SFC) and General Atomics (GA), SFC's parent company, to an October 15, 1993 NRC Staff order. Among other things, the order makes SFC and GA jointly and severally responsible for providing financial assurance for the decommissioning of SFC's facility near Gore, Oklahoma. See 58 Fed. Reg. 55,087 (1993). In a January 25, 1994 memorandum and order, the Board advised the participants that it was granting a motion for leave to intervene filed by petitioner Native Americans for a Clean Environment (NACE) and that a written order detailing its reasons would follow. See Memorandum and Order (Petition for Intervention) (Jan. 25, 1994) at 1-2 (unpublished) [hereinafter January 25 Memorandum and Order]. This memorandum and order sets forth the grounds for that ruling.

The NACE motion confronts the Board with the issue of whether, in an

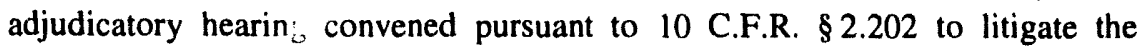
validity of a Staff enforcement order, someone wishing to appear in support of the order can intervene in the proceeding. For the reasons detailed below, we have concluded that (1) as a general matter intervention as of right is 
available to such a petitioner; (2) petitioner NACE has demonstrated that it possesses the requisite interest establishing its standing in this instance; and (3) NACE's intervention motion was timely filed. Additionally, because of the sui generis nature of our determination that in a proceeding on a section 2.202 Staff enforcement order a petitioner can intervene in support of the order, pursuant to 10 C.F.R. $\$ 2.730$ (f) we refer that ruling to the Commission for its review.

\section{BACKGROUND}

Until last summer, SFC operated the Gore facility pursuant to a 10 C.F.R. Part 40 license permitting the use of source material for the production of uranium hexafluoride $\left(\mathrm{UF}_{6}\right)$ and depleted uranium tetrafluoride $\left(\mathrm{DUF}_{4}\right)$. SFC now is moving forward with plans to decommission the facility. Present SFC estimates put the cost of this decommissioning effort at some 86 million dollars. See 58 Fed. Reg. at 55,089.

In accordance with 10 C.F.R. $\$ 2.202(a)(3)$, the October 1993 Staff order at issue here provided that SFC, GA, and "any other person adversely affected by this Order" had until November 4,1993 , to file an answer to, and request a hearing regarding, the order. $58 \mathrm{Fed}$. Reg. at 55,092. The order also states that the issue in any hearing will be "whether this Order should be sustained." Id. SFC and GA filed timely answers and hearing requests on November 2 and 3, 1993, respectively. See [SFC's] Answer and Request for Hearing (Nov. 2, 1993); [GA's] Answer and Request for Hearing (Nov. 3, 1993). On November 18, 1993, the Secretary of the Commission referred these requests to the Chief Judge of the Atomic Safety and Licensing Board Panel for the appointment of a presiding officer, who subsequently appointed this Board to preside over the requested adjudication. See 58 Fed. Reg. 63,406 (1993). See also 59 Fed. Reg. 3382 (1994) (reconstituting Board to add Murphy, J., as alternate member). Also on November 18, petitioner NACE filed a motion for leave to intervene in the proceeding.

NACE describes itself as an Indian-controlled and staffed citizens' environmental organization that endeavors to educate the public about environmental issues, with an emphasis on the nuclear industry. In its motion, NACE states that the organization and its members who live, work, and travel near the Gore facility "would be adversely affected if the October 15 order were reversed or weakened." Motion for Leave to Intervene in Proceeding Regarding [SFC's] and [GA's] Appeal of [NRC's] October 15, 1993, Order (Nov. 18, 1993) at 1 [hereinafter NACE Intervention Motion]. Included with the motion is the affidavit of Ed Henshaw, who declares that he is a NACE member and that NACE is authorized to help represent his interests. In his affidavit, Mr. Henshaw asserts that his home is adjacent to the Gore facility and that his health and safety, 
economic, and social interests will be adversely impacted if the October 1993 order with its directives regarding decommissioning funding is not sustained. See Nov. 23, 1993 Letter from Diane Curran, NACE Counsel, to Samuel J. Chilk, Secretary of the Commission, Affidavit of Ed Henshaw at 1 [hereinafter Henshaw Affidavit].

On December 6, 1993, both SFC and GA filed responses opposing the NACE intervention petition, with GA simply adopting the arguments made by SFC. See [SFC's] Answer in Opposition to NACE's Motion to Intervene (Dec. 6, 1993) [hereinafter SFC Intervention Answer]; [GA's] Answer in Opposition to the Motion to Intervene of [NACE] (Dec. 6, 1993). Included with the SFC filing is the affidavit of its Technical Services Vice President, John S. Dietrich. Mr. Dietrich indicates that Mr. Henshaw's property is more than one mile southeast of the SFC industrial site and more than six-tenths of a mile southeast from some SFC fertilizer ponds that also are to be decommissioned. See SFC Intervention Answer, encl. 2, at 1, П5. See also id., attach. 2. Further, referencing hydrogeological studies done between 1990 and 1992, Mr. Dietrich states that the groundwater flow paths from the SFC industrial facility and the ponds are "generally" westward and away from Mr. Henshaw's property. Id. at 2, ๆ8. Additionally, citing the topographic features of the area, Mr. Dietrich concludes that it is "impossible" for surface water from SFC's industrial facility and the ponds to drain onto Mr. Henshaw's property. Id. at 3, $\uparrow 12$.

In contrast, in a response filed December 13,1993, the Staff declared that because it was conceivable NACE might be adversely affected if the October 1993 order is not sustained, it did not oppose NACE's intervention request, subject to NACE's submission of a valid contention. See NRC Staff's Response to NACE's Motion for Leave to Intervene (Dec. 13, 1993) at 4-5 [hereinafter Staff Intervention Response].

By order dated December 17, 1993, the Board permitted NACE to file a reply to the SFC, GA, and Staff responses to its interve.tion petition. See Order (Reply to Intervention Motion Responses; Prehearing Conference) (Dec. 17, 1993) at 1 (unpublished). NACE responded to this order by filing a December 30, 1993 reply to SFC's response. See [NACE's] Reply to [SFC's] Answer in Opposition to NACE's Motion to Intervene (Dec. 30, 1993) [hereinafter NACE Reply to SFC Intervention Answer]. Included with this reply is the affidavit of hydrogeologist Timothy P. Brown who asserts there is the potential for groundwater contamination to the Henshaw property from the SFC facility, including the industrial site, the nearby pond areas, and outlying agricultural fields on which fertilizer made from raffinate produced at the Gore facility has been spread. See id., attach. C. Among other things, Mr. Brown declares that the available data suggest that groundwater flows in the area are "variable and complex" and may flow in directions other than westward. Id. \9. Mr. Brown 
also states that airborne contamination of the Henshaw property from the SFC site is a possibility. See id. $\uparrow 12$.

SFC subsequently obtained permission to file an additional pleading addressing what it asserts were new factual allegations and arguments in NACE's December 30 reply. See Memorandum and Order (Memorializing Rulings on Pending Motions; Prehearing Conference Agenda) (Jan. 5, 1994) at 2-3 (unpublished). As part of its January 11, 1994 submission, SFC includes the affidavits of hydrogeologists Bert J. Smith and Kenneth H. Schlag, who contest Mr. Brown's assertions regarding groundwater contamination, and radiation protection consultant Thomas E. Potter, who disputes Mr. Brown's statements regarding airborne contamination. See [SFC's] Reply to [NACE's] Supplemental Factual Allegations, New Arguments, and Request for Discretionary Intervention (Jan. 11, 1994), encls. 1-3 [hereinafter SFC Reply to NACE Reply].

NACE, in turn, has submitted an additional affidavit by Mr. Brown.' See [NACE's] Motion for Leave to File Reply Affidavit (Jan. 19, 1994), Reply Affidavit of Timothy B. Brown [hereinafter NACE Reply Affidavit Motion]. In his reply affidavit, Mr. Brown contests portions of the Smith and Schlag affidavits, attempting to counter their position that groundwater flow from the SFC site will not carry contamination to the Henshaw property.

On January 19,1994, the Board conducted a prehearing conference during which it provided the participants an opportunity to address various legal questions it had regarding NACE's intervention request. As was noted previously, in a January 25, 1994 memorandum and order, the Board advised the parties that it was granting NACE's intervention request, with a written order detailing its reasons to follow. See January 25 Memorandum and Order at $1-2 .{ }^{2}$

\footnotetext{
${ }^{1}$ Both SFC and GA contest NACE's request to file this January 19 submission, asserting that NACE should not be given another opportunity to meet the burden that it should have sustained in its first two intervention filings. See [SFC] Response to NACE's Motion for Leave to File Reply Affidavit (Jan. 21, 1994) at 2.3; [GA's] Response to NACE's Motion for Leave to File Reply Affidavit (Jan. 21, 1994) at 1. As we note below, it is not apparent that, left uncontested. NACE's initial showing would have been insufficient to meet its burden on standing. See infra pp. 67-68. Moreover, in granting NACE an opportunity to make a second filing to reply to SFC's response, we contemplated that it would have the last word on the subject of standing. SFC, however, was afforded another opportunity to file without opposition from NACE. See Tr. at 6-7. Although we are not particularly enamored of the "eleventh hour" nature of NACE's filing - coming as it did on the morning of the prehearing conference scheduled to discuss NACE's standing - because NACE's filing deals with matters that were not the subject of discussion at the conference, it is appropriate that NACE be given the opportunity to respond to SFC's additional filing.

2 The Board's January 25 directive also gave NACE until February 8, 1994, to submit its contentions in accordance with 10 C.F.R. 2.714 (b). See January 25 Memorandum and Order at 2. NACE has filed two contentions, which are currently under scrutiny to determine whether they constitute litigable issues. See [NACE's] Supplemental Petition to Intervene (Feb. 8, 1994).
} 


\section{ANALYSIS}

Relative to NACE's intervention request, the participants have raised a variety of concerns about both the general principles governing standing in NRC adjudicatory proceedings and the specific circumstances surrounding NACE's petition. These fall into three categories: (1) in an NRC proceeding involving a challenge to a Staff enforcement order issued under 10 C.F.R. $\$ 2.202$, does a person like NACE who wishes to support the Staff's action have a right to intervene; (2) has NACE made a sufficient showing in this instance to establish its standing as of right; and (3) was NACE's November 18, 1993 intervention motion timely. We deal with each of these issues in turn.

\section{A. Availability of Intervention as of Right to Support a Staff Enforcement Order}

As a threshold matter, ${ }^{3}$ the NACE intervention request requires that we determine whether, for one supporting rather than challenging an enforcement order, the existing statutory and regulatory framework sanctions intervention as of right in a 10 C.F.R. $\$ 2.202$ proceeding. NACE and the Staff assert that intervention as of right is available. NACE Intervention Motion at 3-5; Staff Intervention Response at 4-5. SFC disagrees. It contends that, consistent with the decision of the United States Court of Appeals for the District of Columbia Circuit in Bellotti v. NRC, 725 F.2d 1380 (D.C. Cir. 1983), only those who oppose an NRC enforiement order are persons "whose interest may be affected by the proceeding" so as in qualify for a hearing upon request under section 189a(1) of the Atomic Energy Act of 1954 (AEA), 42 U.S.C. $\$ 2239$ (a)(1), the AEA's hearing provision, and 10 C.F.R. $\$ 2.714$ (a), the regulation governing intervention in all formal adjudications conducted pursuant to 10 C.F.R. Part 2, Subpart G. ${ }^{4}$ See SFC Reply to NACE Reply at 12 . According to SFC, in affirming the Commission's determination that it appropriately could limit the

\footnotetext{
${ }^{3}$ SFC asserts that the initial matter before the Board is whether NACE's intervention motion is timely. See SFC Intervention Answer at 7.8. Because of the somewhat novel nature of the NACE request, we find it appropriate to explore initially the quistion of whether there is a statutory or regulatory basis for its intervention in this proceeding.

4 As part of its attack on NACE's standing in this proceeding, SFC declares that the intervention right afforded by AEA section 189a(1) is not applicable beciuse the October 1993 order issued to SFC and GA does not involve one of the types of licensing actions specified in that provision, i.e., "the granting, suspending, revoking, or amending of any license." See SFC Intervention Answer at 13-15. The Staff agrees with SFC's assertion. See Tr. at 21. NACE, however, maintains that the order "alters a binding norm" so as to constitute a license amendment that comes under the rubric of section 189a(1). See NACE Reply to SFC Intervention Answer at 11.13.

We need not decide this question here, for, as SFC and the Staff also suggest. see Tr. at 21, 24, 33, this issue has no practical impact in these circumstances. This is because the Commission's regulations, 10 C.F.R. 8.714(a), in language identical to that in AEA section 189a(1), provide for intervention in any 10 C.F.R. Part 2 , Subpart G adjudicatory proceeding, including a proceeding initiated under 10 C.F.R. $\$ 2.202$, see id. $\$ 2.700$.
} 
enforcement order proceeding to whether the order "should be sustained," the court in Bellotti noted that "[a]s [the Commission] interpret[s] it, this language limits possible intervenors to those who think the Order should not be sustained, thereby precluding from intervention persons such as petitioner who do not object to the Order but might seek further corrective measures." See SFC Intervention Answer at 20 (quoting Bellotti, 725 F.2d at 1382 n.2 (emphasis added)). This, SFC. maintains, is at least an implicit judicial endorsement of the Commission's intent to preclude anyone who wants to support an enforcement order from participating in any adjudication on the order. See SFC Reply to NACE Reply at 13.

We do not read Bellotti so broadly. The issues before the court in Bellotti were (1) did the Commission have the authority under AEA section 189a to define the scope of the proceeding, and (2) did it abuse that authority by limiting the proceeding's scope to whether the order should be sl!stained. See 725 F.2d at 1381-82. The court held that the Commission did have that authority under section 189a and that it did not abuse its discretion by so defining the scope of a proceeding, even though this precluded intervention by a person championing corrective measures going beyond those in an enforcement order. Indeed, Bellotti is of little or no assistance here because the court simply did not reach the issue now before us. ${ }^{6}$

In resolving that issue, we find much more instructive the Appeal Board decision in Nuclear Engineering Co. (Sheffield, Illinois Low-Level Radioactive Waste Disposal Site), ALAB-473, 7 NRC 737 (1978). In Sheffield, citing Allied-General Nuclear Services (Barnwell Fuel Receiving and Storage Station), ALAB-328, 3 NRC 420 (1976), the Appeal Board found that the attempt of two groups to intervene in support of a pending license renewal application was inadequate because their claim by which they wished to vindicate "broad

\footnotetext{
${ }^{3}$ None of the participants has contested the continuing validity of the Bellotti decision despite the fact that one of the supporting grounds of that decision - the availability to the petitioner of a judicially reviewable request for additional enforcement action under 10 C.F.R. $\$ 2.206$, see 725 F.2d at $1382-83$ - is no longer operative. See, e.g. Nuclear Information Resource Service v. NRC, 969 F.2d 1169, 1178 (D.C. Cir. 1992) (en banc) (in line with Supreme Court's decision in Heckler v. Chaney, 470 U.S. 821 (1985), courts have treated section 2.206 petitions as presumptively unreviewable).

${ }^{6}$ Although we generally would not find it necessary to delve into the parties' arguments in a judicial case that were not addressed in the court's decision, given SFC's substantial reliance on what it understands was the Commission's position in the Bellotti case regarding intervention by anyone supporting an enforcement order, a review of the source of that position does not seem untoward. In its brief to the Bellotti court, in discussing the issue of standing, the Commission declared:

In this instance, in line with the scope of the [order at issue], petitioner Bellotti stands to suffer no harm adverse to his interests by the outcome of the proceeding. Of the two possible outcomes of any hearing, only one - recession of the Staff's order requiring the preparation and implementation of the [corrective] plan - would have been adverse to his professed interests; that outcome, however, will not occur because the licensee has not requested a hearing to contest the order.

Brief for Respondents at 34, Bellotti v. NRC. 725 F.2d 1380 (D.C. Cir. 1983) (No. 82-1932) (footnote omitted) [hereinafter NRC Bellotti Brief I. In the present instance, of course, the Licensee has requested a hearing, raising the specter of the adverse outcome alluded to in the Commission's brief.
} 
public interests" was insufficient to establish the particularized injury needed for intervention as of right. $7 \mathrm{NRC}$ at 741-42. The Appeal Board went on to observe:

It need be added only that we perceive no good reason why any different rule [regarding the need to establish a particularized injury] should apply to the petitioners here merely because, unlike the Barnwell petitioners, they favor rather than oppose the proposal under consideration. Standing to intervene hinges neither upon the litigating posture the petitioner would assume if allowed to participate nor on the merits of the case. Rather, the test is whether a cognizable interest of the petitioner might be adversely affected if the proceeding has one outcome rather than another. And, to repeat, no such interest is to be presumed. There must be a concrete demonstration that harm to the petitioner (or those it represents) will or could flow from a result unfavorable to it - whatever that result might be. In this instance, if in fact the outright denial of the Sheffield application or the imposition of license conditions would pose a threat of injury to petitioners or their members, it should have been easy enough to have provided a bill of particulars on that score. In short, contrary to petitioners' claim on the appeal, to conclude (as we do) that their standing to intervene as of right has not been established is not perforce to foreclose all attempts at intervention in support of an application.

Id. at 743 (citation and footnote omitted). The Appeal Board then remanded the case for further consideration of whether the groups qualified for discretionary intervention. See id. at 743-45.

SFC contends that the Sheffield case has limited value because it was not an enforcement proceeding like this one.7 See $\mathrm{Tr}$. at 51 . Nonetheless, in line with the directive in 10 C.F.R. $\$ 2.714$ (d)(1)(iii) that a pertinent consideration in intervention rulings is "[t]he possible effect of any order that may be entered in the proceeding on the petitioner's interest," we think that decision provides valuable guidance in resolving the issue now before us.

Once SFC and GA requested a hearing relative to the Staff's October 1993 order, as the Appeal Board's analysis in Sheffield suggests, NACE was presented with the likelihood that an adjudicatory proceeding would be conducted that could have two possible outcomes: The Board would fully sustain the Staff's

\footnotetext{
${ }^{7}$ SFC also asserts that the Sheffield decision should be ignored because the case is a pre-Belloti determination, because the discussion quoted above is dicta, and because a later Appeal Board in the Shoreham proceeding declined to rule on the issue of whether intervention to support a license application is permissible. See Tr. at 51-52. We do not find the pre-Bellotti status of the Sheffield decision particularly telling in light of our conclusion that Belloni really did not address the central issue now before us. Further, it is not apparent that the discussion quoted above is dicta given the Appeal Board's further determination to remand the proceeding to consider the availability of discretionary standing, several of the standards for which are "It/he nature and extent of the petitioner's property, financial, or other interest in the proceeding" and "[t]he possible effect of any order which may be entered in the proceeding on the petitioner's interest." Portland General Electric Co. (Pebble Springs Nuclear Plant, Units 1 and 2), CLI-76-27, 4 NRC 610, 616 (1976). Finally, the fact that a divided Appeal Board in Long Island Lighting Co. (Shoreham Nuclear Power Station, Unit I), ALAB-743, 18 NRC 387, 390 n.4 (1983), chose to affirm the dismissal of an intervention petition supporting an application on the grounds of lateness without reaching the question of whether the intervenor had standing does not have any negative impact upon the validity of the analysis put forth in the earlier Sheffield decision.
} 
order or it would not, either because the Board would reject the order in whole or in part or because the order would be modified or withdrawn by some unilateral Staff action or by a settlement between the Staff and the parties contesting the order. ${ }^{8} \mathrm{NACE}$ has indicated that, given these two possible outcomes, only if it is permitted to participate in this proceeding can it protect its interest in seeing that the October 1993 order and the requirements it imposes for decommissioning funding are sustained. See NACE Intervention Motion at 3-4. Therefore, consistent with Sheffield, if NACE can also establish a particularized injury that it or its members will suffer in the event the order is not sustained, it is entitled to standing as of right as a "person whose interest may be affected by the proceeding."

\section{B. NACE's Particularized Injury}

In assessing whether NACE has made the necessary showing of particularized injury to establish its right to intervene in this proceeding, we are constrained to apply contemporaneous judicial concepts of standing. See Cleveland Electric Illuminating Co. (Perry Nuclear Power Plant, Unit 1), CLI-93-21, 38 NRC 87,

\footnotetext{
${ }^{8} \mathrm{SFC}$ also suggests that NACE's interest in maintaining the terms of the October 1993 order is too illusory to provide NACE with a basis to intervene because of the order's provision permitting the Staff to "relax or rescind" any of its conditions upon a demonstration of "good cause." See SFC Intervention Answer at 22-24, $32-33$ (citing 58 Fed. Reg. at 55.092). We cannot agree. As the Staff notes, under 10 C.F.R. $\$ 2.717$ (b), any Staff action of that kind would be subject to review by the Board with input from all parties to the proceeding. See Tr. at 91-92. See also Oncology Services Corp., LBP-94-2, 39 NRC 11, 26 n.12 (1994). In addition, pursuant to 10 C.F.R. $\$ 2.203$, any settlement between the Staff and any of the parties subject to an enforcement order must be reviewed and approved by the Board. In such a circumstance, a participant like NACE would have an opportunity to vindicate its interest in having the order sustained fully by demonstrating why the settlement proposal would not be in the public interest.

${ }_{9}^{9}$ We also see this determination as consistent with the pre-Bellotii Licensing Board decision in Dairyland Power Cooperative (La Crosse Boiling Water Reactor), LBP-80-26, 12 NRC 367 (1980), a case that has been the subject of considerable controversy among the participants before us.

Dairyland was decided under a regulatory enforcement scheme that is different from the current section 2.202 , which was adopted in 1991. See 56 Fed. Reg. 40,664 (1991). Rather than placing a requirement on the person subject to the order, as is now done, the Staff at that time would issue an order directing the subject to "show cause" why corrective measures proposed by the Staff should not be required. The order also provided an opportunity for a hearing on the Staff's proposed action. In Dairyland, the licensee sought a hearing on a Staff order requiring it to show cause why certain facility changes should not be made. An individual and a group sought to intervene in the proceeding to support imposition of the proposed changes. Thereafser, the Staff reversed its position regarding the need for the changes and the licensee moved to dismiss the intervention petitions and terminate the hearing. The Licensing Board concluded that the Staff's change in position did not affect the ability of the petitioners to obtain a hearing to champion their assertion that the Staff's original show-cause proposal was correct and should be maintained. See 12 NRC at 370-72.

SFC seeks to distinguish Dairyland as a pre-Belloni decision. See SFC Intervention Answer at 21 . As we have stated previously, we do not see that case as controlling the matter before us. Rather, the Dairyland Board's explanation regarding the nature of the petitioners' interests relative to the possible outcomes of the proceeding supports a similar result here. See also NRC Bellotri Brief at $34 \mathrm{n.21}$ ("The order modifying llicense at issue in this case] was made immediately effective and was not contested by the licensee. These factors distinguish the instant case from cases like [Dainyland]. In Dairyland, after a matter was contested and referred to a [Licensing] Board for resolution, intervention within the scope of the proposed enforcement action may be permitted because the petitioners could show an adverse effect from a later Staff decision not to require the proposed action." (emphasis in original)).
} 
92 (1993). This requires that we assess whether the intervenor will suffer any "injury in fact" relative to its interests in the proceeding and whether those alleged interests are within the "zone of interests" protected by the pertinent statutes and regulations under which the petitioner seeks to participate in the proceeding. See id.

NACE asserts that its interest in this proceeding is to act, on behalf of itself and its members living near the Gore facility, as an advocate for the legal authority and reasonableness of the October 1993 order that it believes must be sustained to provide funding that will be adequate to ensure the safe cleanup of the SFC site. See NACE Intervention Motion at 3-4. We have no trouble concluding that the interest of intervenor NACE in seeing that the Staff's decommissioning funding order is sustained falls within the zone of interests protected by the AEA. Further, for the reasons detailed below, we find that NACE has shown "injury in fact" sufficient to establish its representational standing in this proceeding. ${ }^{10}$

To establish the requisite injury in fact, a petitioner must allege a concrete and particularized injury that is fairly traceable to the action at issue." See Perry, CLI-93-21, $38 \mathrm{NRC}$ at 92. To fulfill the requirement for alleging a particularized injury, NACE initially presented the Henshaw affidavit described earlier. That affidavit establishes NACE's authority to represent Mr. Henshaw's interests. In the affidavit, Mr. Henshaw also asserts that his home is adjacent to the radiologically and chemically contaminated Gore facility, which raises the possibility that contaminated groundwater and surface water will migrate onto his property. Because of this, he maintains that a failure to decontaminate the facility properly will have detrimental health and safety, economic, and social impacts upon him and his family and that a failure of SFC and GA to provide funding in line with the October 1993 order will jeopardize proper decommissioning of the facility. See Henshaw Affidavit at 1 .

Standing alone, this affidavit likely would be sufficient to establish a concrete and particularized injury to Mr. Henshaw's AEA-protected health and safety interests that is fairly traceable to the action at issue in this proceeding. ${ }^{12}$

\footnotetext{
${ }^{10}$ In its intervention motion, NACE alleges injury both to itself and its members, see NACE Intervention Motion at 3-4, seemingly suggesting that it can be granted standing either on its own as an organization or as a representative of its members. SFC contends, however, that NACE has not made a showing that will sustain a finding of organizational standing, see SFC Intervention Answer at 16-18, an assertion that NACE does not challenge, see NACE Reply to SFC intervention Answer at 13-23. We thus assess its intervention petition only under the standards governing representational standing.

${ }^{11}$ As the Perry decision also indicates, the injury must be likely to be redressed by a favorable decision in the proceeding. See CLI-93-21, 38 NRC at 92. As we noted above, this will in fact be the case in this proceeding. See supra note 8 and accompanying text.

12 As noted above, Mr. Henshaw's affidavit also expresses a concern about "the social and economic impacts of living near a de facto nuclear waste dump," albeit without further elaboration. Henshaw Affidavit at 1 . It is not apparent that these types of interests (as opposed to health and safety concerns) are cognizable in this proceeding.
}

(Continued) 
See Perry, CLI-93-21, $38 \mathrm{NRC}$ at 93. Yet, as we have described above, SFC controverts this affidavit with a series of affidavits from management and technical personnel.

In reviewing these affidavits, we must bear in mind the often-repeated admonition to avoid "the familiar trap of confusing the standing determination with the assessment of petitioner's case on the merits." City of Los Angeles v. National Highway Traffic Safety Administration, 912 F.2d 478, 495 (D.C. Cir. 1990) (citations omitted). To be sure, the merits of the litigation here generally concern the question of responsibility for funding the decommissioning of the Gore facility rather than the extent of the contamination involved and the SFC actions necessary to deal with that contamination. Nonetheless, decommissioning funding and the nature and extent of site characterization and decommissioning activities bear a relationship to those issues that warrants some care in addressing the various factual allegations regarding NACE's asserted bases for its standing.

In fact, the Commission's recent Perry decision appears to reflect a similar concern about reaching the merits prematurely. In that proceeding, a local intervenor group and an individual living near the Perry nuclear plant sought to challenge a proposed license amendment transferring a particular reactor vessel maintenance schedule from the facility's technical specifications to its safety analysis report. The intervenors declared that they would suffer injury by reason of the fact that once the safety-related vessel maintenance schedule was removed from the technical specifications, which can only be changed by license amendment, they no longer would have notice of changes to that schedule or an opportunity to contest those changes in an AEA section 189a(1) hearing. In reversing the Licensing Board's ruling that the intervenors had not established their standing, ${ }^{13}$ the Commission found, consistent with its prior precedent linking standing injury with the potential for consequences for those living near a facility from a safety-related licensing action, "[a]t this stage in deciding threshold standing, we cannot conclude that no potential for offsite consequences is posed by the loss of notice and opportunity for a hearing to challenge future changes to the [maintenance] schedule." CLI-93-21, 38 NRC at $95-96$.

As the Staff's October 1993 enforcement order makes clear, there is uranium contamination of the soil and groundwater on the SFC main processing facility

\footnotetext{
See Perry, CLI-93-21, $38 \mathrm{NRC}$ at $95 \mathrm{n} .10$ (standing requires more than general interests in the cultural, historical, and economic resources of a geographic area). Yet, even assuming they are, this statement is insufficient to identify the type of concrete and particularized injury needed to support intervention.

${ }^{13}$ The Commission reached this conclusion despite the Licensing Board's determination that the intervenors "hald] failed to identify the chain of circumstances culminating in 'offsite consequences' that must be linked to those future changes . . . ." Cleveland Electric Illuminating Co. (Perry Nuclear Power Plant, Unit 1), LBP-92-4, 35 NRC 114, 123 n.45 (1992), rev'd, CL1-93-21, 38 NRC 87 (1993).
} 
and the nearby pond areas with sufficient safety significance to warrant remediation before the property can be released for unrestricted use. See 58 Fed. Reg. at 55,087. What the Dietrich, Brown, Smith, and Schlag affidavits contain are various claims and counter-claims about the potential impact upon the Henshaw property of groundwater flow from that contaminated site. ${ }^{14}$ In line with the Commission's Perry decision, we must review those affidavits to determine whether there is "no potential" for consequences to Mr. Henshaw's property from groundwater flow relative to the contamination at the Gore facility. And to answer this question on the basis of the record before us, we find we need focus only on the matter of the direction and depth of groundwater flow..$^{15}$

Based upon groundwater flow studies relating to the SFC processing facility and the pond areas lying south of the facility, including a July 1991 facility environmental investigation (FEI) report and a May 1992 addendum to the FEI report, Mr. Dietrich (who is not a hydrogeologist) concludes in the initial SFC affidavit that the groundwater flow from the processing site and the ponds is "generally" westward and away from the Henshaw property. SFC Intervention Answer, encl. 2, at 2, \8. In his first affidavit on behalf of NACE, Mr. Brown declares that Mr. Dietrich's statement about groundwater flow being to the west does not account sufficiently for the complex geology underneath the entire area around the SFC site, which could have significant impacts on flow direction. See NACE Reply to SFC Intervention Answer, attach. C., 19 . Mr. Brown finds particularly important a faulted zone that lies about sixth-tenths of a mile east of the SFC facility and runs diagonally from the northeast to the southwest, going under the Henshaw property. See id. $\eta 7(\mathrm{~b})$. Also of concern, according to Mr. Brown, is the fact that the hydrogeology studies relied upon by Mr. Dietrich focused only on the upper groundwater zones and so did not address the not uncommon phenomenon of deeper groundwater levels moving in a different direction from upper level flow. See id. १7(d).

Responding on behalf of SFC, Mr. Smith asserts that the groundwater flow under the SFC site area is well understood and is representative of the adjacent

\footnotetext{
${ }^{14}$ In contrast to the debate about groundwater flow, SFC's challenge to Mr. Henshaw's otherwise unexplicated concern about surface water is never really addressed by NACE. In the face of an analysis in the Dietrich affidavit indicating that the surrounding topography makes surface water flow to the Henshaw property from the SFC facility "impossible," SFC Intervention Answer, encl. 2, at 3, NACE fails to make any rejoinder, see NACE Reply to SFC Intervention Answer at 19-23. The same is true regarding Mr. Brown's assertion in his affidavit that there is the possibility of airborne contamination. See id. attach. C, 112 . Besides the fact that Mr. Brown's opinion concerning airborne contamination is well outside the bounds of his expertise as a hydrogeologist, we have the detailed, unrebutted response to his claims in the affidavit of SFC radiation consultant Potter. See SFC Reply to NACE Repiy, encl. 3. See also NACE Reply Affidavit Motion at 3 n.3 (NACE unable to conduct technical analyses to rebut Potter affidavit in time to make filing). Based on the record now before us, we can only conclude that there is insufficient support for a finding of injury in fact to the Henshaw property from surface water or airborne contamination.

${ }^{15}$ In contrast to its showing in the Schlag affidavit regarding the raffinate spreading fields, see SFC Reply to NACE Reply, encl. 2, on the issue of NACE's injury in fact from processing site and the pond area groundwater migration, SFC has not made any explicit assertion about the impact of the level of contaminants.
} 
areas. See SFC Reply to NACE Reply, encl. 1, at 2, 19. Mr. Smith also maintains that the geology of the site is not overly complex. See id. at 3, \$10. Further, $v$ 'ile not challenging Mr. Brown's assertion that the nearby fault zone running under the Henshaw property could have a significant impact on flow patterns, Mr. Smith nonetheless discounts the relevance of the zone by declaring that "information developed in the FEI shows that ground water in [the processing and pond areas] will not flow in the direction of that fault, and therefore will not be affected by that fault." Id. at 3, $\uparrow 12$ (emphasis in original). Finally, while not contesting Mr. Brown's opinion about the potential for upper and lower groundwater levels to have different flow directions, Mr. Smith declares that his concerns about deeper flow direction are untoward because information in the 1991 FEI report and the 1992 addendum "was sufficient to convince the investigators that the possibility of significant contamination in even lower zones was unlikely and investigation to deeper zones was unnecessary." Id. at 4, ๆ 13.

Based on the record before us, we are unable to conclude that, as the Commission stated in Perry, there is "no potential for offsite consequences" relative to the Henshaw property from SFC site contamination migrating by groundwater flow. SFC's attempt to undercut the significance of the faulted zone as a groundwater path by declaring that groundwater will not flow toward the fault is itself undermined by the FEI report. As FEI charts attached to Mr. Brown's second affidavit indicate, groundwater from the processing site does move south in the direction of the fault. See NACE Reply Affidavit Motion, Reply Affidavit of Timothy B. Brown, attachs. 1-2. At a minimum, this supports Mr. Brown's assertion that the groundwater flow patterns are "variable and complex" and leaves us unable to conclude that there is "no potential" for contaminated groundwater to flow towards the Henshaw property via the faulted zone (or some other pathway). ${ }^{16}$ In addition, SFC itself described the results of the FEI report for the Staff by stating that deeper flow systems are "expected." SFC Reply to NACE Reply, encl. 1, attach. A-2, at HYD 5-2. As Mr. Brown indicated, the potential for upper- and lower-level flows carries with it the possibility of differing flow directions. Having failed to measure the direction of these "expected" deeper flows, SFC is in no position to show that there is "no potential for offsite consequences" relative to the Henshaw property from such deeper flow patterns. ${ }^{17}$

\footnotetext{
${ }^{16}$ Our conclusion in this regard is not affected by the fact that the pond area lies to the south between the processing site and the Henshaw property and that the groundwater flow chart for the pond area shows a generally westerly flow. The difference between the groundwater flows in the processing and pond areas only serves to emphasize that, at least on the basis of the information now before us, the groundwater flows in the area apparently are sufficiently complex that we cannot conclude that there is "no potential for offsite consequences" relative to the Henshaw property. See Perry, CL1-93-21, 38 NRC at 95.

${ }^{17}$ The validity of SFC's decision not to do such studies based on a judgment that the possibility for significant lower-level flow contamination was "unlikely," SFC Reply to NACE Reply, encl. 1, at 4, 113 , may well be 
In sum, on the basis of the NACE and SFC presentations before us, like the Commission in Perry we "cannot conclude that no potential for offsite consequences" exists for the Henshaw property relative to the contamination on the SFC site. Accordingly, we find that there is a sufficient demonstration of injury in fact by NACE to provide standing to intervene as of right in this proceeding.

\section{Timeliness of NACE's Intervention Request}

With the legal basis for its standing thus established, NACE nonetheless faces an additional hurdle to its admission to this proceeding: the timeliness of its intervention motion. The Staff's October 15, 1993 order specified that within twenty days of its issuance, hearing requests had to be filed by those "adversely affected by this Order." 58 Fed. Reg. at 55,092. Acknowledging that it filed its November 18, 1993 intervention motion 2 weeks past that date, NACE maintains that because it was not adversely affected by the order, the 20-day deadline in the order did not apply to it. According to NACE, consistent with the scope of this proceeding as defined by the Bellotti decision, it suffered an adverse impact entitling it to intervention only when SFC or GA (or some other person adversely affected by the order) requested a hearing. The timeliness of its hearing request thus must be gauged in relation to the filing of those hearing requests. See NACE Intervention Motion at 2-3. Finally, NACE contends that even if its intervention motion is untimely, a balancing of the five factors for late-filed petitions set forth in 10 C.F.R. \$2.714(a)(1)(i)-(v) supports admission of its filing. ${ }^{18}$ See NACE Reply to SFC Intervention Answer at 5-10 \& attach. A (resume of Arjun Makhijani).

Not unexpectedly, SFC argues that, consistent with 10 C.F.R. $\$ 2.202$ (a)(3) and the language of the Staff's order, NACE's intervention request was untimely. See SFC Intervention Answer at 8-10. SFC also asserts that NACE is unable to make the required showing under the section 2.714(a)(1) five-factor test for late-

\footnotetext{
sustainable relative to the merits of any future determination about the adequacy of the FEI report or SFC's decommissioning activities generally. In the context of our "no potential for offsite consequences" standing determination here, however, it is insufficient to compel a finding of no injury in fact against NACE. The same can be said for SFC's statement in its description of the FEI report that there is a "low potential" for groundwater movement between the upper-level flow systems and the deeper systems. See id., encl. 1, attach. A-2, at HYD 5-2.

${ }^{18}$ Section $2.714(a)(1)$ has been interpreted to require that the late-filed factors be addressed in the initial late petition. See Boston Edison Co. (Pilgrim Nuclear Power Station), ALAB-816, 22 NRC 461, 466-68 (1985). NACE, however, first addressed the late-filed factors in NACE's reply to SFC's response to NACE's intervention motion. See NACE Reply to SFC Intervention Answer at 5-10. Acknowledging that we have the discretion to permit an intervenor to make such a belated lateness showing, see Pilgrim, ALAB-816, 22 NRC at 468, SFC asserts that the familiarity of NACE counsel with NRC proceedings establishes there is no good cause for NACE's failure to discuss those factors in its initial motion. See SFC Reply to NACE Reply at 2-3. We conclude, however, that NACE's assertion that its petition was not late at all was made in good faith so as to provide good cause for permitting it to address the late-filing factors for the first time in its reply pleading.
} 
filed intervention petitions. See SFC Intervention Answer at 10-13; SFC Reply to NACE Reply at 2-10. In its filing in response to the NACE intervention motion, the Staff seemingly agrees that NACE's request was untimely, but declares that given the short period of time involved, it does not oppose granting the motion. See Staff Intervention Response at 2 n.5. During its presentation at the January 19 prehearing conference, however, the Staff expressed support for NACE's position that its motion was not untimely because it was not "adversely affected" under the terms of the order. See Tr. at 65-66.

The timeliness issue presented by NACE's filing requires that we explore the meaning of, and relationship between, two agency regulations. One is 10 C.F.R. \$ 2.202(a)(3), which requires that an enforcement order inform any person "adversely affected by the order" of his or her right to request a hearing within 20 days of issuance of the order. The other is 10 C.F.R. $\$ 2.714(\mathrm{a})(1)$, the intervention provision that applies to all 10 C.F.R. Part 2, Subpart G proceedings, including section 2.202 enforcement order proceedings. See supra note 4. By its terms it permits "[a]ny person whose interest may be affected by a proceeding" to seek party status subject to any time limits that may be established in an appropriate notice.

If, as NACE (and apparently the Staff) contend, section 2.202(a)(3) does not apply to a petitioner like NACE who wants to intervene in support of the order, the October 1993 order with its "adversely affected by the order" language did not provide NACE with notice of when it had to file a request for intervention. The timing of NACE's intervention request then would be subject to any notice issued in conformity with section $2.714(\mathrm{a})(1)$ to those "whose interest may be affected by the proceeding." On the other hand, if the "adversely affected by the order" language of section 2.202(a)(3) and the language of section $2.714(\mathrm{a})(1)$ providing an intervention opportunity to persons "whose interest may be affected by the proceeding" are coextensive, as SFC maintains, then the deadline specified in the October 1993 order was applicable to NACE and its petition is untimely.

A principal problem with the latter interpretation is that it runs contrary to the usual inference that different language is intended to mean different things. See United States v. Stauffer Chemical Co., 684 F.2d 1174, 1186 (6th Cir. 1982), aff'd, 464 U.S. 165 (1984). The difference in language is readily apparent here. Section 2.202(a)(3) concerns those who suffer adverse effects from the "order"; section 2.714 (in imitation of AEA section 189a) refers to those whose interests may be affected by the "proceeding." Further, as this case illustrates, as between the "order" and the "proceeding," there is a real distinction in terms of the impact on the petitioner's interests.

As we noted in section II.A above, an intervenor may become a party to a hearing to protect its interest in seeing that a Staff enforcement order challenged in the proceeding is sustained. Accordingly, the matter that adversely affects 
this petitioner's interest is not the "order," with which it agrees, but the agency's "proceeding" relative to that order, which carries the potential for overturning or modifying the order in derogation of its interests. The differing language in section 2.202(a)(3) and section 2.714(a)(1) mirrors this distinction flawlessly. ${ }^{19}$

We thus conclude that the NACE (and the Staff) reading of these regulations is the correct one. The language of section 2.202(a)(3) establishing a 20-day deadline for hearing requests, as echoed in the order, was not applicable to NACE. ${ }^{20}$ Instead, its intervention is governed by section $2.714(\mathrm{a})(1)$ and any time limits that are established in accordance with that section.

As it is applicable to govern intervention by NACE in this proceeding, section 2.714(a) states that an intervention petition "shall be filed not later than the time specified in the notice of hearing, or as provided by the Commission, the presiding officer, or the Atomic Safety and Licensing Board designated to rule on the petition and/or [hearing] request . . . " Here, the only agency issuance providing constructive notice of a filing deadline has been the Staff's enforcement order that, as we already have found, was not applicable to NACE. It thus appears that there has not been any agency notice of hearing (or opporiunity for hearing) that specifies a time limit for persons, such as NACE, who wish to intervene to protect an interest in having the order sustained. ${ }^{21}$ NACE's petition,

\footnotetext{
${ }^{19}$ Of course, the inference regarding differing meanings for differing language might be negated by a showing that the purpose or regulatory history behind the language demonstrates that no difference was intended. See Stauffer Chemical Co., 684 F.2d at 1186 . We are unable to find any such a purpose or history here. Instead, the regulatory history of the recently adopted section 2.202 shows that its central purpose was to make clear the agency's authority over both licensees and nonlicensees who are the targets of the enforcement action taken in the order. See 56 Fed. Reg. at $\mathbf{4 0 , 6 6 4 - 6 5}$. These are the persons to whom the "adversely affected by the order" language in section 2.202(a)(3) obviously was directed. This same intent is reflected in the language of the other provisions of section 2.202, which consistently refer to the same type of persons. See 10 C.F.R. 2.202(a)(1) (order must allege charges against "the licensee or other person subject to the jurisdiction of the Commission"); id. $\$ 2.202$ (a)(2) ("licensee or other person" must file an answer within 20 days of order); id. $\$ 2.202$ (b) ("licensee or other person to whom the Commission has issued an order" must respond with an answer that is to deny or admit each charge and may demand a hearing).

${ }^{20} \mathrm{SFC}$ also seeks to rely upon a letter written by one of this Board's members in another section 2.202 enforcement order proceeding as support for the proposition that NACE's intervention is subject to the 20-day time limit specified in section 2.202(a)(3). See SFC Intervention Answer at 9-10. The letter in question was written in response to an inquiry from counsel for a medical clinic concerning the timing for its intervention in a 4-monthold proceeding in which a clinic employee had filed a timely hearing request regarding an order modifying the clinic's license to prohibit him from performing activities under that license. In pertinent part, the letter stated:

Further, once the time specified in the enforcement order for filing a hearing request has expired, an interested person who wishes to obtain party status in an adjudicatory proceeding regarding the order is obliged to petition for late-intervention. Among other things, a late intervention petition must address the factors set forth in 10 C.F.R. $\$ 2.714(\mathrm{a})(1)$.

Id., encl. I. In the context of that proceeding, in which the clinic clearly was a person adversely affected by the order that had failed to meet the section 2.202 (a)(3) deadline, the letter's statement about the applicability of the section $2.714(a)(1)$ factors no doubt was correct. See infra note 22 . Nonetheless, in light of our determination here about the timeliness of NACE's petition, the use in the letter of the term "interested person" was inaccurate. ${ }^{21}$ It stands to reason that without a constructive notice of the deadline for filing a hearing request for these other potential intervenors, there is no apparent point at which the agency can reject a hearing request from such a person as untimely. The administrative inefficiency of such a circumstance is apparent and cries out for some remedy.
}

(Continued) 
therefore, cannot be deemed untimely for failing to meet an appropriately noticed filing deadline.

Yet, even in the absence of any constructive notice, the possibility remains that NACE had actual notice of the pendency of this enforcement proceeding and failed to make a timely intervention request following that notice. See 54 Fed. Reg. 8269, 8272 (1989). NACE asserts that the first time it was given any actual notice relevant to its intervention in this proceeding was on November 8, 1993, when it received service of the SFC and NACE answers requesting a hearing on the October 1993 order. See NACE Intervention Motion at 2. NACE maintains that it acted reasonably thereafter by filing its intervention motion on November 18, 1993. See id. at 3. SFC argues, however, that NACE had actual notice earlier but failed to act promptly to file its intervention petition. According to SFC, because SFC's and GA's February 1993 responses to a Staff demand for information made it apparent that they disagreed with the Staff's approach to decommissioning funding liability, NACE had actual notice that there would be a proceeding when it received the October 1993 Staff enforcement order, which the agency served on NACE. See SFC Intervention Answer at 11.

Given our previous finding that it is NACE's interest in the "proceeding" rather than the "order" that is relevant here, the pertinent actual notice was that affording NACE knowledge that this adjudicatory proceeding would be commenced. The SFC and GA hearing requests received by NACE on November 8 constituted such a notice. And, by filing its intervention motion within 10 days thereafter, NACE acted seasonably relative to that actual notice. Compare 10 C.F.R. $\$ 2.1205$ (c)(2)(i) (hearing request must be filed within 30 days of actual notice).

We thus conclude that, under the circumstances here, NACE's November 18 , 1993 intervention motion was timely filed.22

\footnotetext{
Fortunately, Commission guidance on how to handle this problem already exists in the agency's nules governing informal adjudications in materials and operator licensing cases. It is agency practice to provide notice of only some of the material licensing actions to which AEA section 189a(1) hearing rights attach. See 54 Fed. Reg. 8269, 8270-71 (1989). As the Commission has acknowledged, this can creale a situation in which a hearing will be convened at the request of an interested person who finds out about the licensing action, while others similarly situated have no notice of their right to request and participate in such a proceeding. To rectify the potential inefficiencies (not to mention unfairness) in this situation, the informal hearing rules provide that once an intervenor's hearing request is granted regarding a previously unnoticed action, a notice is to be published in the Federal Register that advises all other interested persons of the proceeding and sets a specific deadline for them to file intervention petitions. See 10 C.F.R. $\$ 2.1205$ (i)(4).

Consistent with this Commission guidance, in the event we find NACE has presented a litigable contention so as to be fully admitted as a party to this proceeding, pursuant to the Board's authority under section $2.714(\mathrm{a})(1)$, we will issue a notice of hearing that invites all other persons whose interest may be affected by this proceeding to intervene by a date certain.

${ }^{22}$ Our conclusion that NACE's intervention motion is timely obviates the need to determine whether its petition can be admitted as untimely. We nonetheless observe that, even if its intervention motion was subject to the 20-day filing date specified in the October 1993 order, NACE has made a sufficient showing to excuse its failure to act by that deadline.
}

(Continued) 


\section{CONCLUSION}

For the reasons stated herein, we find that intervenor NACE's stated interest in protecting the health and safety of its members by ensuring that the Staff enforcement order contested in this proceeding is sustained is cognizable under the agency's statutory and regulatory provisions permitting intervention by those "whose interest may be affected by the proceeding." Further, we conclude that NACE has established its standing to participate in this proceeding by making a sufficient demonstration that the health and safety interests of its members are within the AEA-protected zone of interests and that injury in fact may accrue to those interests that is traceable to the challenged order. ${ }^{23}$ We also find NACE's intervention motion was timely filed in accordance with 10 C.F.R. $\$ 2.714(a)(1)$. Finally, because we perceive the question of whether intervention

\footnotetext{
As an initial mattet, it seems apparent that the agency's procedural rules do not have a provision that explicitly governs an untimely section $2.202(\mathrm{a})(3)$ answer/hearing request. The five late-filed factors in section $2.714(\mathrm{a})(1)$ seemingly provide the appropriate guidance for considering such a filing, however.

Applying those standards relative to the NACE and SFC arguments concerning timeliness, see supra pp. 71-72, we are of the opinion that four of the factors clearly are in NACE's favor. We agree with NACE that under factor one, "good cause" did exist for late filing in light of what we consider to be NACE's good-faith argument that the section 2.202(a)(3) filing deadline was not applicable to one supporting the Staff's order. In that context, NACE's intervention filing within 10 days of receiving notice of the SFC and GA requests to begin this proceeding was reasonably prompt. Regarding factor two - the availability of other means to protect NACE's interests - we cannot agrec with SFC that NACE's right to file a petition seeking Staff action under 10 C.F.R. 82.206 is an adequate alternative to an adjudicatory proceeding. See Washington Public Power Supply System (WPPSS Nuclear Project No. 3), ALAB-747, 18 NRC 1167, 1175-76 (1983). As NACE suggests, this is particularly true when the Staff-initiated action under consideration came about after a process that is the same as that which would result from a successful section 2.206 petition. We also cannot accept SFC's assertion that the presence of the Staff weighs against NACE relative to the fourth factor concerning the representation of the petitioner's interest by other parties. Priot cases have emphasized the potential for a divergence of interests between the Staff and private parties, see id. at $1174-75$ \& $n .22$, a consideration that seems especially relevant here given NACE's assertion that any Staff action in this proceeding to mudify or withdraw the October 1993 order would be inimicable to its interest in seeing that the order is fully sustained, see supra note 8 . Finally, as to factor five, because the scope of this proceeding under Bellotti precludes NACE from advocating measures going beyond those set forth in the order, NACE's admission at this very early stage of the proceeding is not reasonably likely either to delay this proceeding or to broaden the issues before the Board.

The only element for which NACE's showing may be wanting is factor three - the petitioner's assistance in developing a sound record. In support of this factor, NACE proffers the resume of Dr. Arjun Makhijani and asserts that his expertise in nuclear engineering, including technologies and costs associated with nuclear waste containment and disposal, and his fumiliarity with decommissioning issues regarding the SFC facility, will ensure that NACE can make a valuable contribution to record development. As SFC points out, however, it is not apparent how that asserted proticiency provides any help in addressing the issues of liability and funding adequacy that are central to this proceeding. Although we are troubled by NACE's failure to make explicit any link between Dr. Makhijani's purported expertise and these issues, ultimately we do not give this shortcoming much weight. In light of Dr. Makhijuni's apparent expertise, we see this as a pleading deficiency rather than the proffer of a witness who manifestly cannot assist in developing a sound record. Because the other four factors so clearly support NACE's paricipation, we ultimately conclude that this failing is insufficient to tip the balance against permitting late-filed intervention.

${ }^{23}$ Having determined that NACE is entitled to intervention as of right, we do not have to reach its alternative assertion that it should be afforded discretionary intervention pursuant to the balancing test established in Pebble Springs, CLI-76-27, 4 NRC at 616. Nonetheless, assuming such intervention is available in a proceeding regarding a section 2.202 order, it is apparent that petitioner NACE has made a sufficient showing under the Pebble Springs factors.
}

(Continued) 
as of right exists for a petitioner that wants to enter a section 2.202 enforcement order proceeding to support the Staff's order addressed in this memorandum and order is of some moment for the structure of this proceeding, as well as the Commission's adjudicatory process generally, and in order to alleviate any delay in Commission consideration of this matter pending our determination regarding the admissibility of NACE's contentions, ${ }^{24}$ in accordance with 10 C.F.R. $\$ 2.730(f)$, we refer our ruling on this matter to the Commission for its immediate review. Cf. Statement of Policy on Conduct of Licensing Proceedings, CLI-81-8, 13 NRC 452, 456-57 (1981) (in licensing hearings, licensing boards should seek Commission guidance on significant legal or policy questions and should do so in a manner that will avoid delay in the proceeding).

For the foregoing reasons, it is this 24 day of February 1994, ORDERED that:

1. The January 19, 1994 motion of petitioner NACE for leave to file reply affidavit is granted.

2. In accordance with the Board's memorandum and order of January 25, 1994, the November 18, 1993 motion of petitioner NACE for leave to intervene is granted.

3. Pursuant to 10 C.F.R. $\$ 2.730(f)$, the Board refers to the Commission for its review the Board's ruling in section II.A above that in a proceeding on

Pour of the six fectors - asdistances in record dovelopment, avilability of other means to protect the petitioner's

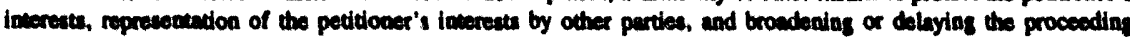
- ane execatially identical to itom we alkendy have addresed relative to the admiscion of NACB's pedition as Ine-Aled. See supra nove 22. As wo indicated there, only one of those factor - aniatunce in recond development - weigh aedinat NACE, although not subetendilly w. Indeed, in the context of discretionary intervention, the negative impact of that factor is further disaipated by the fact that there will be a proceeding even abent incervertion by NACB. Compare Tennessee Valloy Awhorify (Wats Bar Nucles Plant, Units 1 and 2), ALAB-413, 5 NRC 1418, 1422 (1977) (need for strong showing on potential record contribution factor is preatag where, abeen discretionary intervention, no bearing will be held).

Concerning the other two factors - ature and extent of petidioner's intereat in the proceeding and possible effect of any order in the proceeding on that interest - for the ressons we have outlined in cections II.A and I.B above regurding NACE's atanding, we think that the impact of the possible outcomes of this proceeding on the bogitimate health and safery interests of NACE's members is appenent and that, with a beat one representative of the orennization living within approximately a mile of the facility, there is a cognizable pocential for adveres impects flowing from the possible inadequate funding of decommisuloning activities that the Stafr's order is inended to foreatall. Balancing these two factors weighing in favor of NACE's participation along with the four discused above, its seems apparen that NACE should be afforded discretionary intervention in this proceeding.

We note further in this regerd that we do not find especially relovant to any determination on NACE's discredonary intervention statements made by Commissioners during a November 8, 1993 briefing on the sgency's vite decommissioning manugement plan that are included as Attachmen E to NACE's Reply to SFC's Imervention Aniwer. We thus see no need to strike the attachment, as SFC requeats.

${ }^{24}$ Until a determination is made that an intervenor has proffered a litigable contention, a licensing boand's ruling on an intervenoc's party stetus is not final. Our rulings in tis memorandum and order thus are not yet appealable pursuant to 10 C.F.R. 2.714 a See Cincinnati Gas and Electric Co. (Wiltian H. Zimmer Nuclear Power Stadon), ALAB-595, 11 NRC 860, 864-65 (1980). 
a 10 C.F.R. $\$ 2.202$ Staff enforcement order, there is no prohibition against an otherwise qualified petitioner intervening as of right in support of the order.

\section{THE ATOMIC SAFETY}

AND LICENSING BOARD

James P. Gleason, Chairman

ADMINISTRATIVE JUDGE

G. Paul Bollwerk, III

ADMINISTRATIVE JUDGE

Thomas D. Murphy

ADMINISTRATIVE JUDGE

Bethesda, Maryland

February 24, 1994 


$$
=
$$


UNITED STATES OF AMERICA

NUCLEAR REGULATORY COMMISSION

\section{OFFICE OF ENFORCEMENT}

James Lleberman, Director

NORTHEAST NUCLEAR ENERGY COMPANY

The Director, Office of Enforcement, denies a Petition filed by Paul M. Blanch (Petitioner) pursuant to 10 C.F.R. \$ 2.206. The Petition requested that the NRC take enforcement action, in addition to that taken in a May 4, 1993 enforcement action, against Northeast Nuclear Energy Company for certain activities that he alleged constituted violations of 10 C.F.R. $\$ \$ 50.7$ and 50.5 .

\section{ENFORCEMENT POLICY: REOPENING ENFORCEMENT ACTIONS}

In view of the NRC's limited resources, it is normally more appropriate to focus on new enforcement actions, rather than reopen closed actions.

\section{DIRECTOR'S DECISION UNDER 10 C.F.R. $\$ 2.206$}

\section{INTRODUCTION}

On August 2, 1993, Mr. Paul M. Blanch (Petitioner) filed a letter with the Executive Director for Operations of the U.S. Nuclear Regulatory Commission (NRC). The letter requests, pursuant to 10 C.F.R. $\$ 2.206$, that the NRC take enforcement action, in addition to that taken in a May 4, 1993 enforcement action issued to Northeast Nuclear Energy Company (Licensee), for certain activities that he alleges constitute violations of 10 C.F.R. $\$ \$ 50.7$ and 50.5. The letter has been referred to me for response. By letter dated August 23, 1993, this Office 
acknowledged receipt of the Petitioner's request and indicated that a response would be provided in a reasonable time.

\section{BACKGROUND}

On December 18, 1989, the Region I Administrator requested that the NRC's Office of Investigations (OI) conduct an investigation into allegations that, among other things, Petitioner had been subjected to harassment, intimidation, and discrimination (HI\&D) by his Northeast Utilities (NU) management after raising safety concerns. Pursuant to this request, OI conducted an extensive investigation and, on August 31, 1992, issued a Report of Investigation in which it found that:

[Petitioner] who raised the Rosemont transmitter safety concern . . . was the victim of various incidents of HI\&D and attempted HI\&D as a result of his stand on this issue. OI identified those responsible . . . either directly or indirectly, as the [Petitioner's] manager (the systems manager of Electrical Engineering . . .); the director of the [Petitioner's] department (the director of Engineering . . .); the vice president of that department (Generation Engineering \& Construction; since retired), the vice president of Nuclear and Environmental Engineering . . . and the then senior vice president of NE\&O (since resigned).

To assess the OI Report and reach a judgment on enforcement action, the NRC Staff formed a review team that included representatives from Region I, the Office of Nuclear Reactor Regulation, the Office of the General Counsel and the Office of Enforcement. After review and consideration of the OI Report, the staff team arrived at conclusions on a course of action for enforcement. The enforcement action was based in part on a violation of 10 C.F.R. $\$ 50.7$. The Staff determined that the Licensee subjected the Petitioner to HI\&D by the creation and tolerance of a hostile work environment for raising safety issues. The violation was considered particularly significant due to the direct involvement of a senior-level corporate official and because other senior-level corporate officials either knew, or should have known, of the HI\&D, but failed to act in an effective manner to correct the situation, and, therefore, was categorized at a Severity Level II. On May 4, 1993, after consultation with, and approval by, the Commission, the Staff issued a Notice of Violation (NOV) with a $\$ 100,000$ civil penalty for the Severity Level II violation. A civil penalty of $\$ 100,000$ is the largest authorized by the Atomic Energy Act for a single violation. The Staff noted in the letter transmitting the Notice of Violation to the Licensee that the base civil penalty for a Severity Level II violation is $\$ 80,000$ but that, in this case, the civil penalty was increased to $\$ 100,000$ because of the significant management involvement in the violation. In addition, the Staff issued a Demand for Information (DFI) requiring the Licensee to explain (a) 
why the NRC should have confidence that the Licensee will ensure that there is a work environment free of HI\&D with the two supervisors who were found to have discriminated against the Petitioner still involved in safety-related activities; and (b) why, after four senior corporate officials became aware of the harassment and intimidation concerns involving Petitioner, the Licensee was ineffective in promptly terminating the hostile work environment to which the Petitioner was subjected. This action was taken only after extensive and careful review of the OI Report and all of the associated evidence.

Petitioner now requests that the NRC reopen, reconsider, and modify this enforcement action. As grounds for this request, the Petitioner asserts that a letter he received from me, dated July 15, 1993 (responding to his letter of June 4, 1993, in which he stated that many specifics were not addressed in the enforcement action taken against the Licensee), was unresponsive. Specifically, the Petitioner requests that: (1) enforcement action be taken against Dr. Charles F. Sears, former Licensee Vice President of Nuclear and Environmental Engineering, identified by OI as one of those responsible for HI\&D against the Petitioner, for willful violation of section 50.7 and deliberate misconduct as defined by 10 C.F.R. §50.5; (2) a Severity Level I violation be imposed upon the Licensee corporate officer responsible for directing action against two of the Petitioner's former subordinates, which the Petitioner alleges was a retaliatory action in violation of section 50.7 and deliberate misconduct as defined by section 50.5 ; (3) three Severity Level I violations be imposed upon three Licensee corporate officers that OI concluded were responsible for HI\&D against the Petitioner for violations of section 50.7 and deliberate misconduct as defined by section 50.5 ; (4) a Severity Level I violation be issued for actions by Mr. Edward Richters, Licensee attorney, and a Severity Level II violation be issued to Mr. Thomas Schaffer, Licensee manager, for threatening certain individuals with letters of reprimand if they did not talk with Licensee contract attorneys prior to being interviewed by the OI, for violation of section 50.5; and (5) a minimum of a Severity Level II violation be issued for actions in violation of sections 50.7 and 50.5 by Mr. Allen Pollack, Licensee Manager of Internal Auditing, who allegedly was aware that an audit of Petitioner's engineering group was in retaliation for Petitioner's engaging in protected activity, for auditing Petitioner's group using falsified credentials, and coming to invalid conclusions based on invalid documentation. Each of these requests is addressed below.

\section{DISCUSSION}

In essence, Petitioner requests that the NRC reopen, reconsider, and modify the enforcement action that NRC has taken against the Licensee for its discriminatory action against the Petitioner. In view of the NRC's limited resources, it 
is normally more appropriate to focus on new enforcement actions, rather than reopen closed actions. The NRC's Enforcement Policy in 10 C.F.R. Part 2, Appendix C, addresses the matter of reopening enforcement actions. Specifically, section XIII of the Enforcement Policy provides that:

(ilf significant new information is received or obtained by NRC which indicates that an enforcement sanction was incorrectly applied, consideration may be given, dependent on the circumstances, to reopening a closed enforcement action to increase or decrease the severity of a sanction or to correct the record. [Emphasis added.]

Petitioner's requests will be judged against this standard.

\section{Request for Enforcement Action Against Former Vice President Charles Sears}

From its review of the OI Report and the associated evidence, the NRC Staff was fully aware of OI's conclusion, and the evidence related thereto, that Dr. Sears contributed to the discriminatory use of the Licensee's internal audit process by his involvement in the initiation or conduct of the audits of Petitioner's activities and that Dr. Sears was either directly or indirectly responsible for the HI\&D of Petitioner. Petitioner has presented no new evidence or information with regard to Dr. Sears' involvement in these matters.

\section{Request That a Severity Level I Violation Be Imposed Upon the Licensee Corporate Officer Who Allegedly Was Responsible for Improper Action Against Petitioner's Subordinates}

From its review of the OI Report and the associated evidence, the NRC Staff was fully aware of OI's conclusion, and the evidence related thereto, that the Licensee's Vice President-Generation Engineering and Construction, Vice President-Nuclear and Environmental Engineering, and a Senior Vice President contributed to the discriminatory use of the Licensee's internal audit process by their involvement in the initiation and/or conduct of audits of Petitioner's subordinates. The NRC Staff was also aware of, and carefully evaluated, OI's conclusion that one of these officials improperly attempted to influence the audit report. In addition, the Staff reviewed the evidence indicating that two of Petitioner's subordinates were suspended as a result of the audit. All of that information was considered by the Staff when it formulated the original enforcement action in this case. 


\section{Request That Three Severity Level I Violations Be Imposed Upon Three Licensee Corporate Officers Responsible for HI\&D Against Petitioner}

From its review of the OI Report and the associated evidence, the NRC Staff was fully aware of Ol's conclusion that the Licensee's Vice PresidentGeneration Engineering \& Construction, Vice President-Nuclear and Environmental Engineering, and a Senior Vice President contributed to, and were directly or indirectly involved in, discrimination against the Petitioner. In addition, from its review of the evidence in the case, the Staff viewed the problem as being particularly significant due to the direct involvement of one of the vice presidents and because other very senior-level corporate officials - the CEO, the President, the Executive Vice President, and a Senior Vice President - either knew, or should have known, of the HI\&D but failed to act in an effective manner to correct it. These matters were considered and factored into the Staff's formulation of the original enforcement action.

\section{Request That a Severity Level I Violation Be Issued for Actions by Licensee Attorney Edward Richter and a Severity Level II Violation Be Issued to Licensee Manager Thomas Shaffer for Threats to Employees to Be Interviewed by $\mathrm{OI}$}

As indicated in the May 4, 1993 letter transmitting the enforcement action to the Licensee, the NRC was fully aware of the fact that Messrs. Richters and Shaffer indicated to several individuals that letters of reprimand would be issued if the individuals did not talk with Licensee attorneys prior to being interviewed by OI. The Staff was also aware of the fact that this position was changed after an employee complained to a consultant of the Licensee who brought the matter to high-level Licensee management attention. See letter from James Sneizek to Northeast Nuclear Energy Company, May 4, 1993, at 4. These matters were factored into the Staff's formulation of the original enforcement action in this case.

\section{Request That a Severity Level II Violation Be Issued for Actions by Licensee's Manager of Internal Auditing, Allen Pollack, for Auditing Petitioner's Engineering Group Using Falsified Credentials and Coming to Invalid Conclusions Based on Invalid Documentation}

From its review of the OI Report and the associated evidence, the NRC Staff was fully aware of evidence indicating that the audits of Petitioner and his subordinates, conducted under the authority of Licensee's Manager of Internal Auditing, were biased by their reliance on data that should have been known to be unreliable, by the failure of the auditors to properly review or follow up 
on the explanations given by the Petitioner and his subordinates, and by other irregularities in the conduct and process of the audits as described in the NOV issued on May 4, 1993. The Staff was also well aware that the Petitioner viewed the audit as a vehicle to discredit him. Indeed, the Staff viewed the use of the Licensee's internal audit process in this case as contributing to the creation of a hostile work environment which formed, in part, the basis for the Notice of Violation and civil penalty that were issued in this case.

On each of the above matters, the NRC Staff carefully evaluated and considered the evidence in arriving at its judgment on the appropriate enforcement action in the case. Although the Petitioner may disagree with the Staff's judgment, Petitioner has provided no new evidence or information that would warrant reopening the enforcement action.

\section{Summary}

In sum, apart from requesting action pursuant to 10 C.F.R. $\$ 2.206$, the Petitioner's letter of August 2, 1993, merely restates a number of the points previously made in his June 4, 1993 letter. As explained in my July 15, 1993 letter, the NRC arrived at its enforcement decision within the latitude afforded by the NRC Enforcement Policy. To reiterate, with regard to that enforcement action, the related OI Report and all the associated evidence were reviewed in considerable detail by the NRC Staff, representatives from Region I, the Office of Nuclear Reactor Regulation, the Office of the General Counsel, and the Office of Enforcement. It was only after careful consideration of all that evidence, including the evidence related to the specific matters that Petitioner has cited in his petition, that the Staff arrived at its conclusion and decided on a course of action. Further, in the case at issue, the Commission approved the NRC Staff's proposed action. The Petitioner has provided no new information, facts, or allegations that differ from what the Staff considered when it formulated that enforcement action and has provided no justification for reconsideration of that action.

\section{CONCLUSION}

In accordance with Commission policy, absent significant new information, closed cases normally are not reconsidered. In conclusion, I deny the petition in this instance because the enforcement action previously taken by the NRC on this matter was based on an extensive review of, and considered judgment on, the facts of the case, was within the guidance of the Enforcement Policy, and was approved by the Commission, and the Petitioner has failed to provide 
information not previously considered in arriving at the enforcement decision in this matter.

A copy of this Decision will be filed with the Secretary of the Commission for the Commission to review in accordance with 10 C.F.R. \$2.206(c). As provided by that regulation, the Decision will constitute final action of the Commission 25 days after issuance, unless the Commission, on its own motion, institutes a review of the decision within that time.

\section{FOR THE NUCLEAR \\ REGULATORY COMMISSION}

James Lieberman, Director

Office of Enforcement

Dated at Rockville, Maryland, this 9th day of February 1994. 
UNITED STATES OF AMERICA

NUCLEAR REGULATORY COMMISSION

\section{OFFICE OF NUCLEAR MATERIAL SAFETY AND SAFEQUARDS}

Robert M. Bernero, Director

In the Matter of

\section{U.S. DEPARTMENT OF ENERGY \\ (Hanford Site)}

Fobruary 22, 1994

The Director, Office of Nuclear Material Safety and Safeguards, denies a Petition filed by F. Robert Cook requesting that the Director of the Office of Nuclear Material Safety and Safeguards exercise his authority to require a license application from the U.S. Department of Energy with respect to certain highlevel radioactive wastes, consisting of spent nuclear fuel generated at Nuclear Regulatory Commission-licensed nuclear reactors, stored in hot cells and the 200 Area Burial Ground at the Hanford Site in the State of Washington. As basis for this request, the Petitioner asserts that the hot cells and 200 Area at the Hanford Site are storage facilities for high-level radioactive wastes subject to section 202(3) of the Energy Reorganization Act of 1974 and the regulatory authority of the Nuclear Regulatory Commission (NRC).

\section{ENERGY REORGANIZATION ACT: NRC LICENSING OF DOE FACILITIES}

Research and development, rather than receipt and storage of high-level radioactive waste, is the primary use of hot cells in Buildings 324, 325, and 327 at the Pacific Northwest Laboratory (PNL) with respect to NRC-licenseegenerated materials. Accordingly, these PNL buildings are not subject to regulation by the NRC pursuant to section 202(3) of the Energy Reorganization Act of 1974. 


\section{ENERGY REORGANIZATION ACT: NRC LICENSING OF DOE FACILITIES}

Neither the Hanford 200 Area Burial Ground nor either of its subareas (200 East and $200 \mathrm{West}$ ) is used primarily for receipt and storage of high-level radioactive waste from NRC-licensed activities. Accordingly, these facilities are not subject to regulation by the NRC pursuant to section 202(3) of the Energy Reorganization Act of 1974.

\section{DIRECTOR'S DECISION UNDER 10 C.F.R. \$ 2.206}

\section{INTRODUCTION}

By Petition dated July 25, 1991 (Petition), F. Robert Cook (Petitioner) filed a request pursuant to 10 C.F.R. $\$ 2.206$ that the Director of the Office of Nuclear Material Safety and Safeguards exercise his authority to require a license application from the U.S. Department of Energy (DOE) with respect to certain high-level radioactive wastes (HLW), consisting of spent nuclear fuel generated at Nuclear Regulatory Commission-licensed nuclear reactors, stored at locations at the Hanford Site in the State of Washington.

By letter to Mr. F. Robert Cook, dated September 3, 1991, I acknowledged receipt of the Petition. Notice of receipt was published in the Federal Register on September 12, 1991 (56 Fed. Reg. 46,449). I subsequently determined that additional information was needed concerning DOE activities at Hanford, and on August 19, 1992, I wrote to DOE to request such information. A copy of this letter was sent to Mr. Cook. DOE provided its response on April 2, 1993.' Based on the information obtained from DOE, and for the reasons given below, I have now concluded that the Petitioner's request should be denied.

\section{BACKGROUND}

The Petition addresses spent nuclear fuel, generated in licensed activities, that is alleged to be located in certain burial trenches and hot cells at Hanford. The issue that I must resolve is whether such spent fuel is in fact so located at any of the facilities at Hanford and, if so, whether those facilities are subject to regulation by the Nuclear Regulatory Commission (NRC). The Petitioner

\footnotetext{
'Letter dated April 2, 1993, from Jill E. Lytle, Deputy Assistant Secretary for Waste Management, Environmental Restoration and Waste Management, Department of Energy, to Robert M. Bernero, Director, Office of Nuclear Material Safety and Safeguards, NRC.
} 
has identified, as the applicable provision of law, section 202 of the Energy Reorganization Act of 1974, 42 U.S.C. \$5842, which reads in part as follows:

Sec. 202. . . the Nuclear Regulatory Commission shall . . have licensing and related regulatory authority pursuant to chapter 6, 7, 8, and 10 of the Atomic Energy Act of 1954, as amended, as to the following facilities of the [Department of Energy]:

(3) Pacilities used primarily for the receipt and storage of high-level radioactive wastes resulting from activities licensed under such Act.

I agree with the Petitioner that this is the applicable statutory provision and I will proceed, therefore, to consider whether any or all of the activities, of the types identified by the Petitioner, at Hanford are within the scope of this law.

\section{DISCUSSION}

DOE has advised me that over the years it has acquired certain spent fuel and fuel materials from NRC-licensed reactors for use in research and development activities. DOE has described the R\&D activity as being work "that supports the R\&D activities and projects of the Materials Characterization Center, the West Valley Demonstration Project, the Hanford Waste Vitrification Project, the MK42 Processing Project, and the Federal Republic of Germany heat sources."2 There are also studies of stored spent fuel behavior and canister fabrication. These materials are maintained primarily in hot cells of Building 324 at the Pacific Northwest Laboratory (PNL) with lesser amounts located in Buildings 325 and 327 at PNL. After undergoing destructive examination, the remnants, or amounts exceeding the test requirements, are retained temporarily in one of these PNL Buildings' hot cells or at the Hanford 200 Area low-level waste (LLW) burial ground (which consists of the 200 East Area and the 200 West Area) pending disposal. The question presented by the Petition is whether, under section 202(3) of the Energy Reorganization Act, those facilities are subject to the licensing and related regulatory authority of the NRC. Based on the information obtained from $\mathrm{DOE}^{3}$ and an NRC site visit that included PNL Buildings 324, 325, and 327, I conclude that research and development, rather than receipt and storage of HLW, is the primary use of these PNL Buildings with respect to NRC-licensee-generated materials and that the PNL Buildings are not subject to licensing and related regulatory authority of the Commission.

\footnotetext{
${ }^{2}$ lbid.

${ }^{3}$ lbid.

"NRC "Trip Report - Site Visit of Pacific Northwest Laborutory and Department of Energy Hanford 200 Area," dated January 21, 1994.
} 
As indicated above, it appears that certain wastes generated in the course of licensed activities are now located in the Hanford 200 Area Burial Ground. I will assume, for purposes of this review, that those wastes are "high-level radioactive waste" within the meaning of the Energy Reorganization Act. Even so, I find that the Commission has no jurisdiction with respect to the 200 Area, since neither the 200 Area, nor either of its subareas (200 East and 200 West) is being used "primarily" for the purpose of receipt and storage of the commercially generated wastes.

DOE has explained that:

The Hanford 200 Area Burial Ground is a single facility, consisting of a number of trenches intended for the disposal of DOE-owned low-level waste. The 1,700-acre active part of the facility holds approximately 400,000 cubic meters of low-level wastes, approximately 1.100 cubic meters of which is of NRC-licensed reactor origin . . . IT) IThe latter represents materials not used or consumed in the tests at the PNL facilities, which is held here temporarily, pending disposition. An overwhelming percentage of the materials at this site are low-level wastes resulting from DOE's nuclear-materials production operations or operations of the DOE reactors that are not subject to NRC licensing."

The presence of licensee-generated wastes does not in and of itself dictate that NRC exercise regulatory authority. The Commission's jurisdiction exists only if the facility in which those wastes are stored is used "primarily" for the purpose of such storage. DOE's need for the Hanford 200 Area Burial Ground arises out of defense-related programmatic requirements, in particular "the disposal of DOE-owned low-level waste." Serving that need is clearly the primary purpose for which the burial ground has been established. The material from NRC-licensed activities is commingled with greater amounts of unrelated materials, and there is no discrete area set aside for the materials from NRClicensed activities. Also based on the site visit of November 9 and 10, 1993, NRC has been informed that the health and safety controls of the employees and the security for the 200 Area are under one management plan covering all radioactive materials, including NRC-licensee-generated spent fuel and fuel materials. I conclude that neither the Hanford 200 Area nor either of its subareas (200 East and 200 West) is used primarily for receipt and storage of HLW from NRC-licensed activities. Accordingly, these areas are not subject to regulation by NRC.

\footnotetext{
SLoter from Jill Lytle, April 2, 1993, supra note 1.

${ }^{6}$ NRC Trip Report, supro note 4.
} 


\title{
CONCLUSION
}

In summary, neither the PNL Buildings 324, 325, and 327 nor the Hanford "200 Area" LLW burial ground (or either of its subareas, 200 East and 200 West) is used primarily for the receipt and storage of HLW from NRC-licensed activities. Accordingly, these facilities are not subject to regulation by the NRC. Therefore, the Petitioner's request for action under 10 C.F.R. \$2.206 is denied.

\section{FOR THE NUCLEAR \\ REGULATORY COMMISSION}

\author{
Robert M. Bernero, Director \\ Office of Nuclear Material Safety \\ and Safeguards
}

Dated at Rockville, Maryland,

this 22d day of February 1994. 

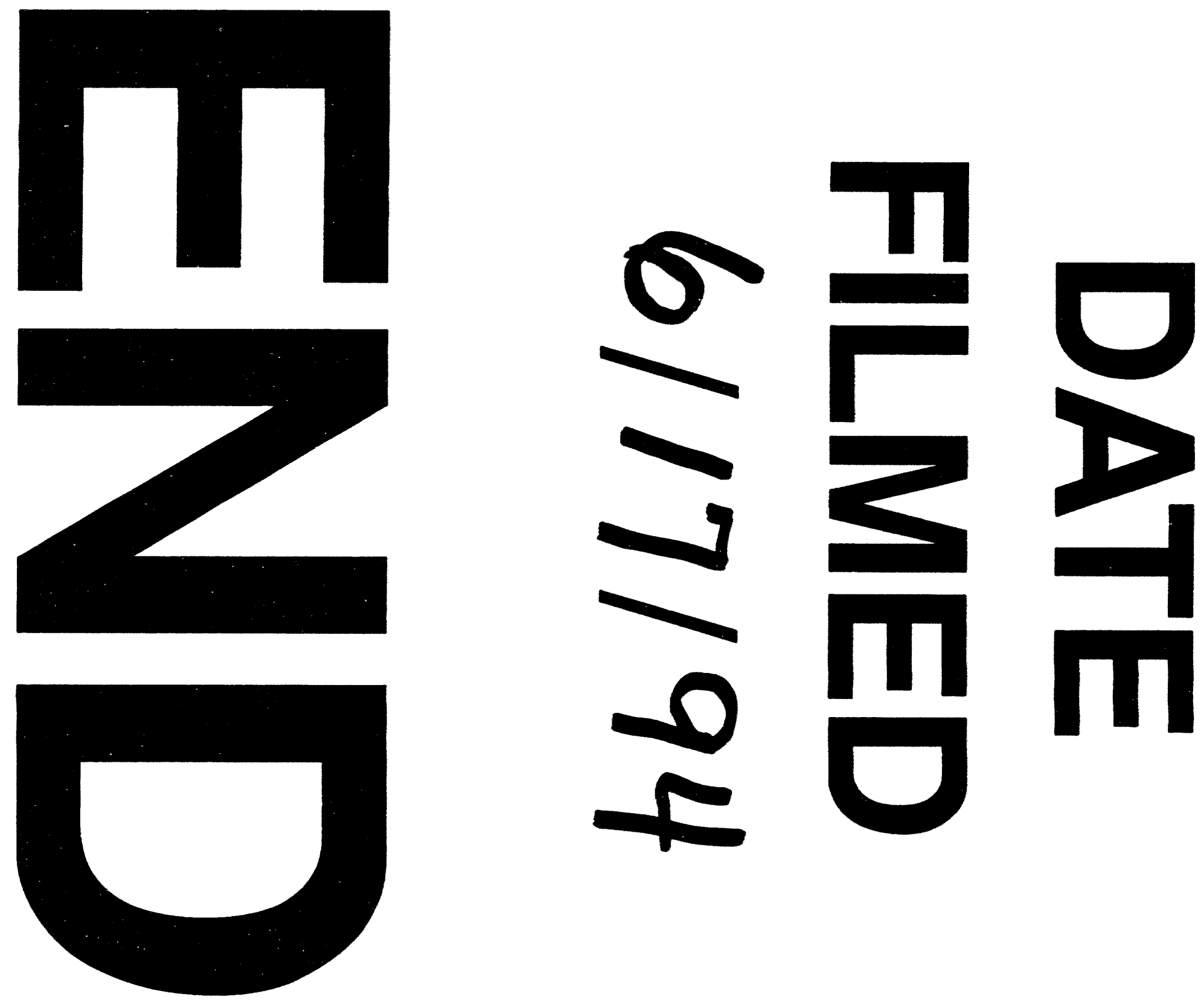


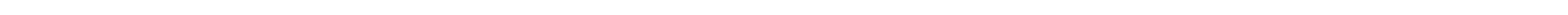

